\title{
A Review on Synthetic Ester Liquids for Transformer Applications
}

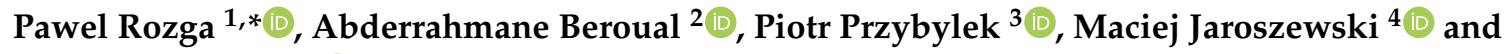 \\ Konrad Strzelecki ${ }^{1}$ (D)
}

1 Institute of Electrical Power Engineering, Lodz University of Technology, Stefanowskiego 18/22, 90-924 Lodz, Poland; konrad.strzelecki@dokt.p.lodz.pl

2 Ecole Centrale de Lyon, CNRS, Ampère UMR5005, University of Lyon, 36 avenue Guy de Collongue, 69134 Ecully, France; Abderrahmane.Beroual@ec-lyon.fr

3 Institute of Electric Power Engineering, Poznan University of Technology, Piotrowo 3A, 60-965 Poznan, Poland; piotr.przybylek@put.poznan.p1

4 Department of Electrical Engineering Fundamentals, Wroclaw University of Science and Technology, Wybrzeze Wyspianskiego 27, 50-370 Wroclaw, Poland; maciej.jaroszewski@pwr.edu.pl

* Correspondence: pawel.rozga@p.lodz.pl; Tel.: +48-42-631-26-76

Received: 23 October 2020; Accepted: 1 December 2020; Published: 4 December 2020

\begin{abstract}
Synthetic esters have become more and more popular in last few decades, explaining the increasing number of units filled with this liquid year by year. They have been investigated under different aspects, both from the fundamental point of view and breakdown mechanisms, well as from the application point of view. However, their use in high voltage equipment is always a challenge and deeper knowledge of the various aspects that can be encountered in their exploitation is needed. The intent of this review paper is to present the recent research progress on synthetic ester liquid in relation to the selected issues, most important for ester development in the authors' opinion. The described issues are the breakdown performance of synthetic esters, lightning impulse strength and pre-breakdown phenomena of synthetic esters, synthetic esters-based nanofluids, combined paper-synthetic ester based insulating systems, application of synthetic ester for retro-filling and drying of mineral oil-immersed transformers, DGA(dissolved gas analysis)-based diagnosis of synthetic esters filled transformers as well as static electrification of synthetic esters. The different sections are based both on the data available in the literature, but above all on the authors' own experience from their research work on synthetic ester liquids for electrical application purposes.
\end{abstract}

Keywords: synthetic esters; power transformers; liquid insulation

\section{Introduction}

The search for new insulating liquids respectful of the environment as well as the improvement of existing liquids for high voltage applications is a permanent task; the goal being the improvement of the properties of insulating systems in which these liquids have to be used while keeping the electrical properties required during exploitation in a given electrical device. Significant progress has been made in this area in recent years. This is how a new generation of insulating liquids appeared, namely liquid esters. These represent a potential alternative to mineral oils traditionally used in power transformers [1-8]. Among the ester liquids, the natural esters, synthetic esters and blended esters may be mentioned. In terms of natural esters, many companies have offered their products for many years [9-16]. These products differ from each other to a small extent and the differences result mainly of the source from which the esters are obtained (refining from soya, sunflower, rapeseed etc.) In turn, the blended esters were proposed recently and have not been so popular as natural ones yet. 
Their main advantage in relation to the other esters is a lower viscosity in comparison to classical esters, which are closer to those of mineral oils [17-19]. While the number of natural esters available on the transformer market is growing year by year, the market of synthetic esters for electrical purposes is quite niche and only individual products are available for common use [20,21]. However, the last few years seemed to change this tendency, providing some new products worthy of consideration.

The 1970s are considered to mark the beginning of work into the use of synthetic esters for electrical applications. The first transformer unit in which a synthetic ester was introduced, was put into operation in 1976. In subsequent years, the works devoted to synthetic ester liquids were intensified. At present, the synthetic esters have found an application mainly in distribution and special transformers of relatively low powers and voltages. This situation results from the good environmental properties of synthetic esters (biodegradability and high fire point), which have been allowed to easily meet the restrictive environmental requirements for specific application such as for example high speed railways, wind turbines and shopping centers [4,20-23]. However, within the synthetic ester-based transformer applications, a continuous increase in the value of rated power and nominal voltage is being seen. Currently, the highest nominal voltage of transformer units using synthetic esters has reached $400 \mathrm{kV}$. With the development of synthetic ester-based applications, the standards describing the requirements for fresh synthetic esters have been developed too. The IEC (International Electrotechnical Commission) 61099 Standard "Insulating liquids-Specifications for unused synthetic organic esters for electrical purposes" [24] has been modified for years and its current form is dated to the year 2011. In turn, the ASTM (American Society for Testing and Materials) has just started to work on its own document entitled "New standard specification for less-flammable synthetic ester liquids used in electrical equipment", which is being considered currently.

The present paper is a review of the present knowledge and data available in the literature and more particularly is based on the authors' own experience from their research work into synthetic ester liquids and their application in a high voltage area. The subjects that will be dealt with are:

- Chemical properties of synthetic esters;

- $\quad$ AC and DC breakdown voltage of synthetic esters;

- $\quad$ Lightning impulse breakdown voltage and pre-breakdown phenomena of synthetic esters;

- Synthetic ester-based nanofluids;

- Combined paper-synthetic ester-based insulating systems;

- $\quad$ Application of synthetic esters for retro-filling and drying of mineral oil-immersed transformers;

- DGA-based diagnosis of synthetic ester-filled transformers;

- $\quad$ Static electrification of synthetic esters.

\section{Chemical Properties of Synthetic Esters}

Synthetic esters are chemical compounds resulting from a direct reaction of an alcohol molecule and a carboxylic acid molecule, called an esterification reaction. Polyols, i.e., molecules that contain more than one hydroxyl group, are usually used in this reaction. Each of the hydroxyl groups can participate in the reaction with another carboxylic acid molecule. As a result, the carbon chain from a polyol molecule is the backbone to which the carbon chains derived from carboxylic acid molecules are attached by ester bonds. In the synthesis process, one can use saturated molecules (containing only single bonds between carbon atoms) or unsaturated molecules (where there are double or triple bonds between carbon atoms). Since the compounds containing unsaturated bonds show less stability, the use of saturated compounds is preferred. Figure 1 presents schematically the esterification process $[4,25]$. 


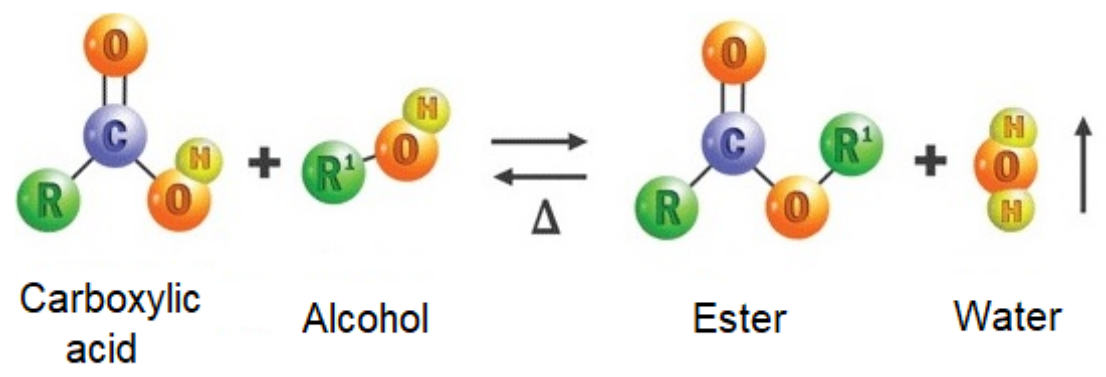

Figure 1. Graphical presentation of the esterification mechanism.

An example of a synthetic ester used for electrical purposes is a pentaerythritol ester. It consists of four ester groups, COOR, that are placed at the end of the cross structure of the main compound. The alkyl (organic) groups from $\mathrm{R}_{1}$ to $\mathrm{R}_{3}$ in this compound may be either the same or different and are typically from $\mathrm{C}_{5} \mathrm{H}_{11}$ to $\mathrm{C}_{9} \mathrm{H}_{19}$ (with saturated carbon chains). Such a chemical structure of synthetic esters makes it quite a stable compound $[4,25,26]$. Figure 2 presents the simplified structural formula of the compound of the mentioned type of ester.<smiles>[R]C([R])([R])C(=O)OCC(COC(=O)C([R])([R])[R])(COC(=O)C([R])([R])[R])COC(=O)C([R])([R])[R]</smiles>

Figure 2. Simplified structural formula of pentaerythritol ester: R1, R2, R3—organic groups.

The requirements specified in the IEC 61099, which should be met by the fresh synthetic ester as received, are set in Table 1. For each parameter, the standard suggested for the determination of the distinctive properties is quoted. It is important to point out that all synthetic esters available on the transformer market fulfill these requirements $[20,21]$.

Table 1. Requirements for fresh synthetic ester for electrical purposes as per IEC 61099.

\begin{tabular}{cccc}
\hline Properties & Unit & Standard for Evaluation & Required Value \\
\hline Density at $20{ }^{\circ} \mathrm{C}$ & $\mathrm{kg} / \mathrm{dm}^{3}$ & ISO 3675 & Max. 1 \\
Viscosity at $40{ }^{\circ} \mathrm{C}$ & $\mathrm{mm}^{2} / \mathrm{s}$ & ISO 3104 & Max. 35 \\
Flash Point & ${ }^{\circ} \mathrm{C}$ & ISO 2719 & 250 \\
Fire Point & ${ }^{\circ} \mathrm{C}$ & ISO 2592 & 300 \\
Pour Point & ${ }^{\circ} \mathrm{C}$ & ISO 3016 & Max. -45 \\
AC Breakdown Voltage & $\mathrm{kV}$ & IEC 60156 & Min. 45 \\
Dissipation Factor at $90^{\circ} \mathrm{C}$ & - & IEC 60247 & Max. 0.03 \\
Resistivity at $90{ }^{\circ} \mathrm{C}$ & $\mathrm{G} \Omega \mathrm{m}$ & IEC 60247 & Min. 2 \\
\hline
\end{tabular}


The density, but first of all the viscosity of a dielectric liquid, are the key parameters responsible for its cooling properties, which are important for the proper operation of the power transformer. It is well-known that viscosity of the liquid decreases with increasing temperature. The synthetic esters are more viscous than mineral oils over a wide range of temperatures. However, the differences are reduced when the temperature increases. For example, the viscosity of the synthetic ester Midel 7131 is $70 \mathrm{~mm}^{2} / \mathrm{s}$ at $20^{\circ} \mathrm{C}$ and $5.25 \mathrm{~mm}^{2} / \mathrm{s}$ at $100{ }^{\circ} \mathrm{C}$ while mineral oil viscosity is $22 \mathrm{~mm}^{2} / \mathrm{s}$ and $2.6 \mathrm{~mm}^{2} / \mathrm{s}$ at 20 and $100{ }^{\circ} \mathrm{C}$ respectively. Hence it is clearly seen that the difference decreases from three to two times comparing 20 and $100{ }^{\circ} \mathrm{C}[1-4,20,21]$.

The synthetic ester liquids are eco-friendly products characterized by high level of biodegradability. Hence, in this field they provide a great alternative to other types of insulations used in power transformers such as mineral oils, silicone oils as well as to dry-type transformers. Since the synthetic esters are readily biodegradable, its usage in power transformers avoids environmental damage when leakage occurs as well as enabling reductions in containment measures. Typically, synthetic esters achieve $10 \%$ degradation by day 3 and on the 28 th day they reach $89 \%$ degradation. With a high level of fire point, the synthetic esters significantly increase the fire safety of transformers and reduce the need for fire protection equipment. Synthetic esters are treated as non-flammable products of K3 class. Their flash and fire points reach temperatures higher than 250 and $300^{\circ} \mathrm{C}$ respectively, which are much higher values than the corresponding temperatures characterizing mineral oils $\left(150\right.$ and $\left.170{ }^{\circ} \mathrm{C}\right)$. At the same time, synthetic esters show low smoke properties. Typically, mineral oils produce thick black smoke while synthetic esters are characterized by thin white smoke which is not as dense as the smoke generated by mineral oils. Through an extremely low pour point $\left(-50^{\circ} \mathrm{C}\right)$, transformers filled with synthetic esters become a highly effective solution in colder climates $[4,20,21,27,28]$.

Synthetic esters have an exceptionally high moisture tolerance. The water content in the insulating liquid determines a number of its properties affecting the conditions and safety of the transformer operation. The water content in the insulating liquid is most often expressed in ppm by weight, and is measured using the standardized Karl Fischer titration method [29]. More and more often, the moisture of insulating liquids is described by means of relative saturation (RS), which is the ratio of the moisture content to the water saturation limit in the insulating liquid at a given temperature, and is usually expressed as a percentage. This parameter can be measured with a capacitive sensor installed in a transformer. In turn, the water saturation limit (water solubility) expresses the maximum concentration of dissolved water that can exist in insulating liquid at thermodynamic equilibrium at a specified temperature and pressure [30].

Synthetic esters are characterized by a much greater water solubility compared to other insulating liquids used in transformers. Different water solubility should be explained by the different polarities of particles of these liquids. Mineral oil is non-polar or is weakly polar. By contrast, ester linkages that are present in natural and synthetic esters make these liquids polar. Synthetic esters may have $2-4$ ester linkages per molecule. Polar molecules tend to be most strongly attracted to other polar molecules like water. This allows for the creation of hydrogen bonds between the hydrogen atoms that belong to the water molecule and the oxygen atom which belongs to the ester molecule $[4,31,32]$.

The water saturation limit in the insulating liquid can be calculated using the formula:

$$
\log S=A-\frac{B}{T}
$$

where:

$A$ and $B$-water saturation coefficients characteristic for the given insulating liquid, $T$-liquid temperature in Kelvin.

Table 2 summarizes the $A$ and $B$ coefficients for the new synthetic ester Midel 7131 taken from the literature, while Figure 3 shows the water saturation limit in the function of temperature determined on the basis of these coefficients and by means of the Equation (1). 
Table 2. Water saturation coefficients for synthetic ester Midel 7131.

\begin{tabular}{ccccc}
\hline \multicolumn{2}{c}{ Water Saturation Coefficients } & \multicolumn{2}{c}{ Water Saturation Limit, ppm } & Reference \\
\cline { 1 - 4 } $\mathbf{A}$ & $\mathbf{B}$ & $\mathbf{2 0}{ }^{\circ} \mathbf{C}$ & $\mathbf{5 0}{ }^{\circ} \mathbf{C}$ & \\
\hline 5.42 & 629 & 1881 & 2975 & {$[30]$} \\
5.320 & 608.28 & 1758 & 2739 & {$[32]$} \\
5.4166 & 581.95 & 2700 & 4128 & {$[33]$} \\
5.6614 & 695.74 & 1941 & 3224 & {$[34]$} \\
7.1790 & 1191 & 1307 & 3115 & {$[35]$} \\
\hline
\end{tabular}

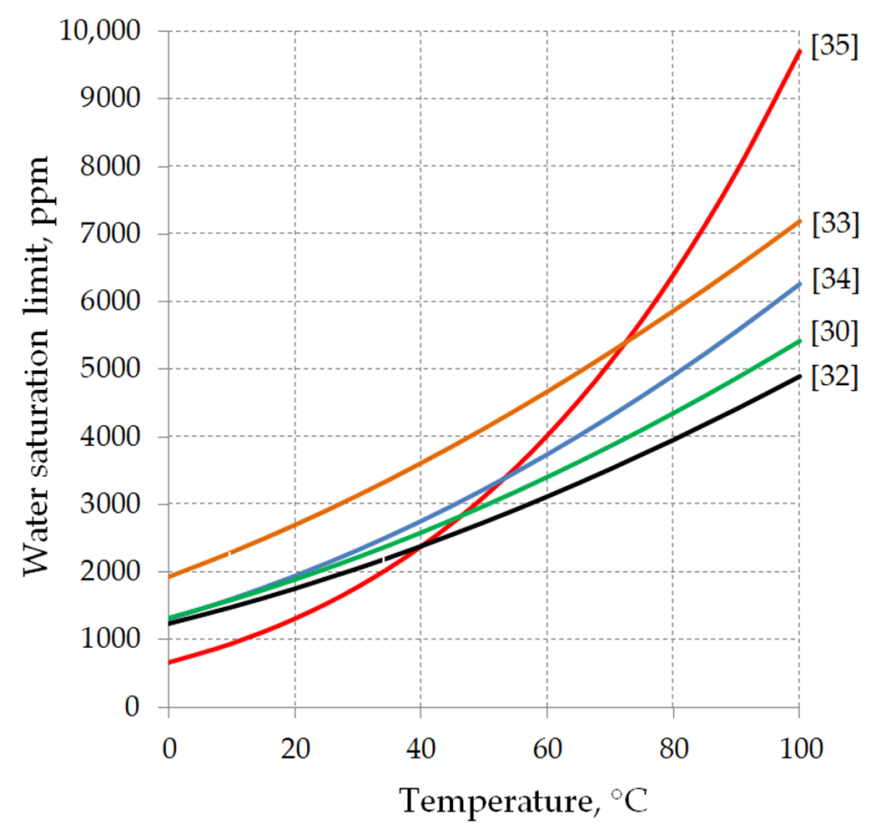

Figure 3. Water saturation limit in the function of temperature for synthetic ester Midel 7131 determined on the basis of water saturation coefficients taken from [30,32-35].

As shown in Figure 3, the water saturation limit, determined on the basis of water saturation coefficients given by various researchers, varies widely depending on the method that has been used to determine these coefficients. For example, for the temperature of $20^{\circ} \mathrm{C}$, the discrepancy in the results of the water saturation limit is as high as $1393 \mathrm{ppm}$. For further consideration, the water saturation coefficients provided in [30] was chosen. This choice is due to the fact that these coefficients were determined based on the results obtained during a Round Robin Test carried out by the Cigre D1.52 working group (WG). These factors represent an average value calculated basing on the results obtained from three methods in five different laboratories [30]. The results of the water saturation limit obtained on the basis of the A and B coefficients given by the Cigre WG are similar (especially in the temperature range from $0{ }^{\circ} \mathrm{C}$ to $50^{\circ} \mathrm{C}$ ) to the values presented in [32,34].

In accordance with $[24,36]$, the water content in the synthetic ester (for untreated liquid as received) cannot exceed the value of $200 \mathrm{ppm}$, corresponding to a relative saturation equal to about $10 \%$ at $20^{\circ} \mathrm{C}$. In the case of such a high water content as in an ester, the drying process should be carried out before filling the transformer tank. In accordance with the standard [37], the water content in esters in service should not exceed the value of $400 \mathrm{ppm}$. This value is considered to be satisfactory for $35 \mathrm{kV}$ or lower voltage equipment. Unfortunately, this standard does not specify the temperature for which the given water content limit applies. For the value of water content in the synthetic ester equal to $400 \mathrm{ppm}$, for $20^{\circ} \mathrm{C}(\mathrm{S}=1881 \mathrm{ppm})$ and $50^{\circ} \mathrm{C}(\mathrm{S}=2975 \mathrm{ppm})$, the relative saturation of the ester is equal to $21.3 \%$ and $13.4 \%$, respectively.

The abovementioned acceptable high moisture content in synthetic esters is treated as an advantage from the viewpoint of interaction with solid insulation. The moisture from cellulose oxidation may 
be absorbed by the esters, which extends the lifetime of cellulose insulation by slowing down its aging $[38,39]$. In the same area, the synthetic ester dielectric strength is highly resistant against moisture content. The mentioned values of 200 or $400 \mathrm{ppm}$ do not cause a reduction in AC breakdown voltage (AC-BDV) of a synthetic ester when it is measured in accordance with IEC 60156 Standard $[4,20,21,40]$. Reduction of this value is observed only at a moisture content of approximately $600 \mathrm{ppm}$, which is much higher than the $20 \mathrm{ppm}$ which decreases mineral oil AC-BDV significantly.

Synthetic esters also have a higher electrical permittivity compared with mineral oils, which is an advantage for the distribution of electrical fields in the paper-dielectric liquid insulating systems of transformers $[3,4,41,42]$. The benefits of synthetic esters are indicated when adding nanoparticles, which at least similarly as in the case of mineral oils, improve the dielectric characteristics of esters [43-48]. The mentioned chemical properties of synthetic esters showed that they have found applications in the so-called retro-filling process. It involves the replacement of mineral oil in a transformer on ester liquid and thus reducing the potential environmental impact [49-53]. There are also some studies where the benefits of synthetic esters connected with its water solubility are used in the process of drying transformers [54-58]. The chemical structure of synthetic esters was found to be a reason for some disadvantages in the field of their behavior under lightning impulses (LIs): the dielectric performances of synthetic esters under these stresses are the worse ones [26,59-63]. Moreover, the lack of stability of the dielectric dissipation factor in the condition of thermal treatment, storage and transport is treated as an undesirable property of synthetic esters [64,65]. In addition, it has been found that due to the higher viscosity of ester liquids, impregnation of the solid insulation with synthetic esters is less effective under the same impregnation conditions than in the case of mineral oil $[19,66]$. Regarding static electrification, synthetic esters have an electrostatic charging tendency (ECT) stronger than mineral oils $[67,68]$. One of the open problems, which is influenced by the chemical properties of synthetic esters, is that of using the dissolved gas analysis (DGA) technique to assess the condition of in-service transformers filled with synthetic esters $[69,70]$.

\section{Breakdown Characteristics of Synthetic Esters}

\subsection{AC and DC Breakdown Voltage}

AC breakdown voltage (AC-BDV) of a dielectric liquid is usually determined according to the standard [40]. As in the case of other dielectric liquids (mineral oils, natural esters), synthetic esters, in the form ready for filling transformers, are characterized by AC-BDV at least higher than $60 \mathrm{kV}$, but this value is often higher than $70 \mathrm{kV}$. However, some experimental work uses statistical approaches to analyze a wider range of data than that required in the mentioned standard. In [71], Martin and Wang analyzed 100 values of the AC-BDV of three dielectric liquids namely mineral oil, natural ester and synthetic ester using statistical approaches such as Gaussian and Weibull distributions to find correlations between the results obtained and to determine the withstand voltage defined as a voltage level for which the risk of failure is low at an acceptable level. Shortly, the results showed a strong similarity between the liquids such as all of them may be capable in acting as transformer liquid insulation. In turn, in [72], the authors tested the influence of conducting particles on the AC-BDV of ester liquids and mineral oil. They used two parallel plane electrodes with a $10 \mathrm{~mm}$ gap. They found that in all cases the conductive particles present in liquid volume significantly reduce the breakdown voltage of the liquids tested. However, this reduction is more visible in the case of mineral oil. It is because of the higher viscosities of both esters considered-the motions of the conductive particles in more viscous synthetic and natural esters are much slower than in mineral oil. In [73], the synthetic ester (tetraester) was tested together with three types of natural ester liquids and three types of naphtenic mineral oils. Similarly as in [71], the conformity of experimental data (32 values of AC-BDV in each case) with the Normal and Weibull distributions were checked and a comparison was made between the considered liquids. It was found from these studies that, in a quasi-uniform electric field (sphere electrodes with a $2.5 \mathrm{~mm}$ gap), the differences between liquids are minimal. 
The synthetic ester tested had a AC-BDV intermediate between the natural esters and the mineral oils considered. Similar statistical behavior of synthetic esters with mineral oil and natural esters was noticed also in [74], but with some advantages (higher median of AC-BDV and lower standard deviations) for the natural ester liquids (vegetable oils). However, the obtained results in each case exceed $60 \mathrm{kV}$, which is enough of a value for the dielectric liquids to be applied in devices of nominal voltages equal to $69 \mathrm{kV}$ or higher. The available data are limited in the case of DC stress-based tests of synthetic esters [75-77]. In [75,77] the authors compared simply the DC-BDV between selected types of dielectric liquids and their mixtures in a quasi-uniform electric field created by a sphere-to-sphere electrode system. When comparing liquids alone, there are no obvious differences between them. Statistically, the mean positive DC-BDV according to [75] is very similar. However, a decreased trend is noticed such as synthetic esters not having the highest value of DC-BDV and mineral oil having the lowest. Nothing new was noticed when comparing the probability distributions: the trend of mean values is valid whatever the considered quantile. Still, the synthetic ester seems to have the best properties under DC. In [77], Reffas et al. tested the liquids under DC voltage and found that olive oil (a new type of vegetable oil) seems to be the most resistant against DC stress for both polarities. However, a synthetic ester is comparable quantitively with mineral oil. Xiang et al. [76] reported totally different conclusions concerning the DC-BDV. These conclusions were based on measurements in a point-to-sphere electrode arrangement representing non-uniform electrical field distributions. Comparing synthetic esters and mineral oil, the authors showed a significant difference between the DC-BDV of both liquids. Mineral oil had higher DC-BDV for both polarities and independently of the considered electrodes gap (from 2 to $30 \mathrm{~mm}$ ). The authors also investigated the streamers behavior in both liquids. They observed that in the condition of the experiment, there were no obvious differences in the shape of streamers recorded photographically corresponding with mineral oil and the synthetic ester. Similarly, the correlation between the stopping length of the streamers and their apparent charge were identical.

It appears from the above that it is difficult to obviously state whether synthetic esters behave similarly to mineral oil and other alternative liquids under AC and DC stresses. Based on a standard approach (2.5 mm gap and two sphere electrodes), there are no data indicating worse synthetic ester properties. They are rather treated as a good alternative for mineral oil similarly as natural esters. However, in a non-uniform electric field, the experimental data are not so optimistic and synthetic esters show some negative traits that are consistent with the observations under the lightning impulse voltages described later.

\subsection{Breakdown Voltage and Associated Phenomena}

Since synthetic esters started to be applied in power transformers, lightning impulse breakdown voltage (LI-BDV) as well as pre-breakdown and breakdown phenomena under this type of stress, have become issues for the special attention of researchers [25,26,59-63,74,78-86]. Impulse breakdown and pre-breakdown phenomena of synthetic ester liquids have been studied mainly at standard LI voltage $1.2 / 50 \mu \mathrm{s}$ and at non-uniform electric field distributions.

A comparison of LI-BDV and switching impulse breakdown voltages (SI-BDV) of synthetic esters with Envirotemp FR3 natural ester and mineral oil Gemini X, have been presented in a comprehensive way in $[26,79]$. The authors performed a wide range of tests on these liquids using a sphere-sphere electrode system of $12.5 \mathrm{~mm}$ diameter and a spacing gap d of $3.8 \mathrm{~mm}$. They analyzed the influence of voltage polarity and testing methods used for the determination of LI-BDV of the considered liquids. First, they found that mineral oil is characterized by slightly higher values of breakdown voltage (both lightning and switching), independently of the voltage waveform. The reduction of mean breakdown voltage of esters was in percentage $15 \%$ for the lightning impulse stress and $8 \%$ for the switching impulse stress. Second, the analysis of the voltage polarity show similar results: lower LI-BDV characterizes synthetic esters and natural esters and this is true for both polarities. On the other hand, four different testing methods were applied to compare the 50\% LI-BDV: rising-voltage 
method when one shot per step was applied, rising-voltage method where three shots per step were applied, up-and-down method and finally multiple-level method. In each case, the best lightning performance characterized mineral oil. Synthetic and natural ester had clearly worse properties within the considered voltage stress. The results borrowed from [79] are summarized in Table 3.

Table 3. 50\% LIBVs of the liquids tested with the use of various methods, $\mathrm{d}=3.8 \mathrm{~mm}$ [79].

\begin{tabular}{cccc}
\hline Method & $\begin{array}{c}\text { Synthetic Ester } \\
(\mathbf{k V )}\end{array}$ & $\begin{array}{c}\text { Natural Ester } \\
\mathbf{( k V )}\end{array}$ & $\begin{array}{c}\text { Mineral Oil } \\
\mathbf{( k V )}\end{array}$ \\
\hline $\begin{array}{c}\text { Rising-voltage 1 } \\
\text { shot/step } \\
\text { Rising-voltage } 3\end{array}$ & 258.0 & 239.3 & 276.4 \\
shots/step & 205.0 & 200.4 & 251.9 \\
Up-and-down & 223.2 & 212.9 & 232.8 \\
Multiple-level & 248.9 & 230.8 & 270.0 \\
\hline
\end{tabular}

However, the $1 \%$ breakdown probability (called a withstand voltage) determined from the two-parameter Weibull plots shows results more favorable for both esters. The $1 \%$ LI-BDVs for esters were $153.1 \mathrm{kV}$ and $151.0 \mathrm{kV}$ for synthetic esters and natural esters, respectively, which were only slightly lower than the corresponding withstand voltage of mineral oil $(156.7 \mathrm{kV})$.

In contrast to the results presented in [79], Rozga et al. [62] proposed for the assessment of lightning performance of synthetic esters the approach based on the IEC 60897 Standard [87]. The $25 \mathrm{~mm}$ gap of point-to-sphere electrode arrangement and step method were applied for LI-BDV determination. The authors tested two synthetic esters, namely Midel 7131 and Envirotemp 200, which were then compared with Shell Diala naphtenic mineral oil. Independent of voltage polarity, the results obtained by the authors in the form of average values from 20 measurements indicate the similar values of LI-BDV for all three liquids tested with small deviation in favor of the esters at a positive polarity and in favor of the mineral oil at negative polarity (approximately $4-5 \mathrm{kV}$ in relative values). This was confirmed by Rozga et al. [86] when testing a new synthetic ester liquid under a negative polarity. The authors obtained statistically identical negative LI-BDVs for synthetic esters as well as natural esters and mineral oil. However, opposite to the results presented in [62], positive LI-BDV was much higher for mineral oil than for both tested ester liquids.

In another work, Reffas et al. [74] compared the positive LI-BDVs of synthetic esters with olive oil, rapeseed oil and mineral oil. The tests were performed for a sphere-to-sphere electrode system with a $2.5 \mathrm{~mm}$ gap distance using the up-and-down method. The 1, 10, 50 and 90\% breakdown probabilities indicate a lower lightning strength of the synthetic ester among the other considered liquids. For example, the median BV of synthetic esters was similar to the median of mineral oil and the mineral oil-olive oil mixture $(20 \%$ to $80 \%)$, while in relation to the fresh olive oil and rapeseed oil, this value was definitely lower.

In turn, the paper [80] presents the results for three liquids, namely mineral oil, synthetic ester and natural ester, for the point-sphere electrode system and two spacing gaps of 5 and $10 \mathrm{~cm}$. The tests were performed under an impulse voltage of $0.5 \mu$ s rise time and $1400 \mu$ s tail. For both gaps, similar results were obtained for ester liquids. For positive polarity, slightly higher values characterized the natural ester, while for negative polarity, the synthetic ester had a higher LI-BDV. Comparing the results concerning esters to those obtained for mineral oil makes both esters look worse. While for the $5 \mathrm{~cm}$ gap and positive polarity the difference is not high (around few $\mathrm{kV}$ ), for $10 \mathrm{~cm}$ and a positive polarity and both gaps at negative polarity, the differences reached even $50 \mathrm{kV}$.

Wider study using an electrode system of non-uniform field distribution, was carried out by Liu and Wang [60]. The authors compared a synthetic ester with a natural ester and mineral oil at gap distances which varied from 25 to $100 \mathrm{~mm}$ for positive polarity and from 15 to $75 \mathrm{~mm}$ for negative ones. Except for $25 \mathrm{~mm}$ for positive polarity, where the LI-BDVs for all three liquids tested were almost identical, for the rest of the gaps and both polarities, ester liquids have lower BVs than 
mineral oil. In general, as the electrode gap increases, the differences between esters and mineral oil increases. However, comparing only ester liquids, a slightly higher LI-BDV characterized the tested synthetic ester.

In the work [85], the authors extended their analyses by placing the pressboard interface in parallel to the electrode system axis. Three gaps were considered: 25,50 and $75 \mathrm{~mm}$ respectively; the liquids tested being the same as in [60]. The authors concluded that in terms of lightning impulse voltage, the pressboard did not influence the relationships between the liquids tested and noticed from the studies without the pressboard. For both voltage polarities, $50 \%$ breakdown voltage was lower in the case of esters. Note that it is well known that, in the case of a divergent electric field, the insertion of a pressboard barrier greatly improves the breakdown voltage whatever the type of oil, voltage waveform and polarity; the improvement is all the more important as the dimensions of the barrier are large.

Regarding the pre-breakdown phenomena in synthetic esters, the attention should be mainly focused on the parameters characterizing discharges (streamers) such as inception voltage, shape of discharge or stopping length of the streamers.

Concerning the inception voltage, the reported results indicate that, in a point-plane electrode system, the streamers in synthetic esters are initiated at similar values as in the case of mineral oil $[59,63,81]$. Furthermore, the impact of the radius of curvature of the high voltage electrode (point) on the streamer initiation in the synthetic ester is the same as for mineral oil. Figure 4 gives an example of comparison of the inception voltages of the three liquids tested taken from [81].

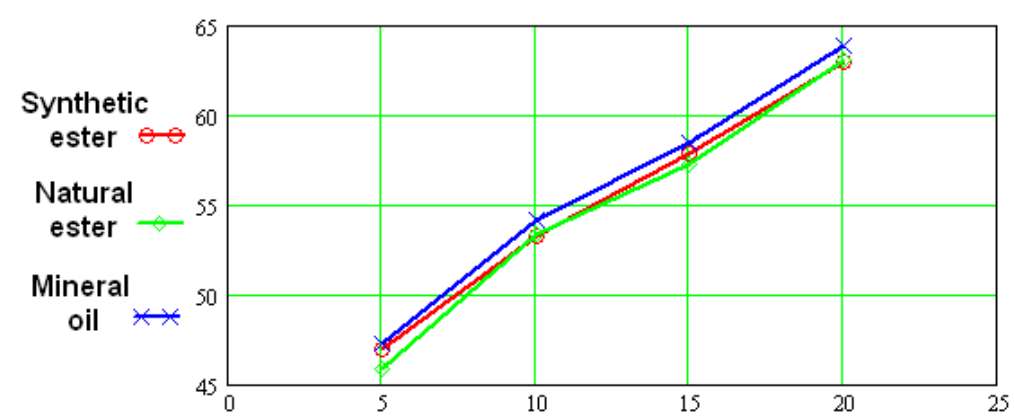

a)

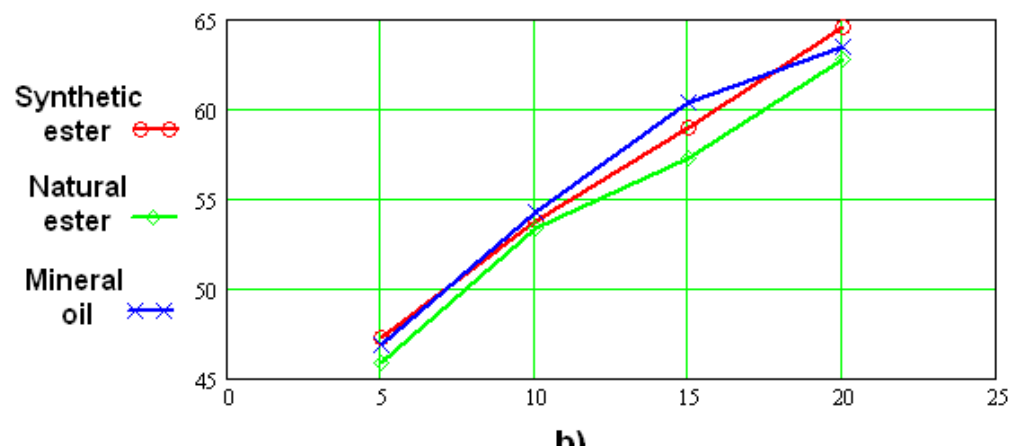

b)

Figure 4. Inception voltage of streamers versus gap distance: (a) negative polarity of lightning impulse, (b) positive polarity of lightning impulse; $x$-axis represents gap distance in $(\mathrm{mm}), y$-axis represents inception voltage in $(\mathrm{kV})$ [81].

The authors of the mentioned works did not observe any difference in the spatial shapes of the streamers recorded photographically when they developed in esters and mineral oils at a voltage lower than the breakdown voltage. Figure 5 gives examples of streamers shapes recorded using a shadowgraph technique. The streamers at the inception voltage are characterized also by similar propagation velocities $[59-63,78,80,81]$. 


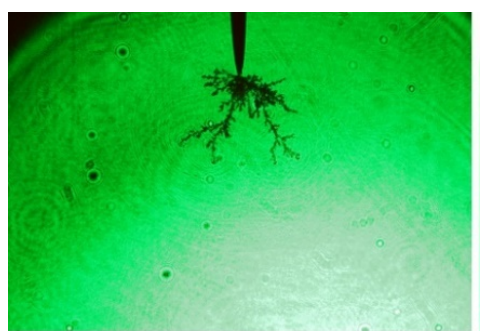

a)

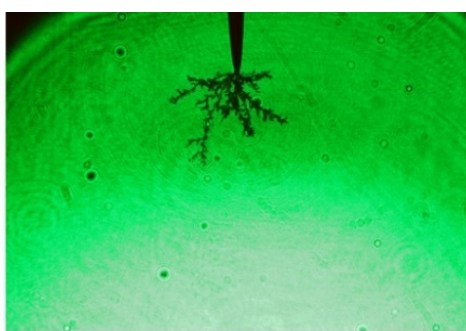

b)

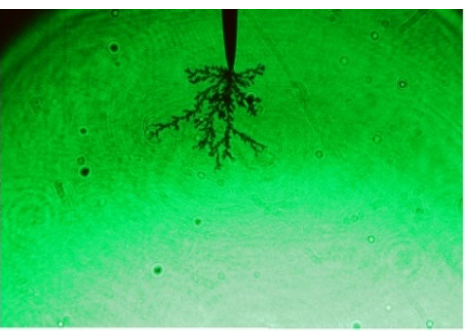

c)

Figure 5. Photographs of negative streamers in: (a) synthetic ester, (b) natural ester, (c) mineral oil; $\mathrm{d}=20 \mathrm{~mm}, \mathrm{~V}=65 \mathrm{kV}$.

A parameter often used when investigating the streamer development is their stopping length (L). Stopping length is the final length the streamer reaches during its propagation for a given voltage level. In general, the stopping length of streamers propagating in synthetic esters is longer than that of streamers in mineral oil, for the same experimental conditions. The well-known relationship that the stopping length increases with the applied voltage is valid also in the case of ester liquids for both voltage polarities $[59,60,63,77,78,86]$.

A significant factor that describes liquid behavior under lightning impulse voltage is propagation velocity of the discharges (typically average value). That is the commonly considered quantity in the studies of streamers in liquids [15,18,59-63,80-86,88-92]. Typically, the propagation velocity increases with the increase in the testing voltage. In an assessment of dielectric liquids on the basis of propagation velocity, the so-called acceleration voltage has become a very important factor. It includes the voltage, which causes the sudden change of the propagation mode of the streamers from slow to fast. Concerning synthetic esters, for small gaps (up to 25-30 mm), the propagation velocity seems to be identical to that of streamers developing in mineral oil when considering the voltages equal to or below the breakdown voltage $[60,62,74,83,84]$. However, when increasing the testing voltage above the breakdown voltage, the differences for the mentioned small gaps appear between the streamers behavior in synthetic ester and mineral oil. The acceleration voltage of streamers in synthetic ester is lower, which means that they are more susceptible to the appearance of fast and energetic discharges. Figure 6 gives an example confirming this fact.

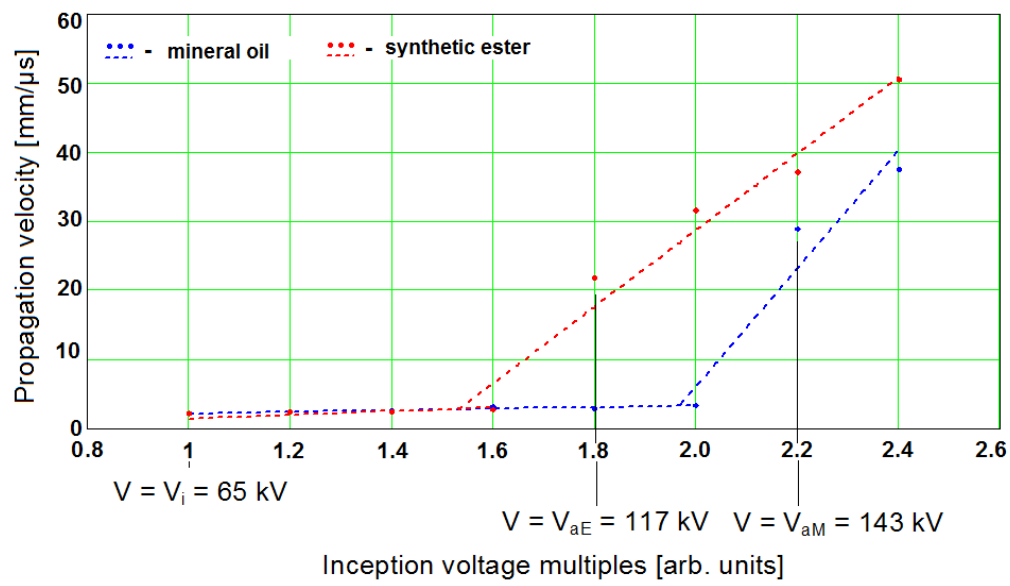

Figure 6. Relationship between the propagation velocity of positive streamers and multiples of inception voltage: $d=20 \mathrm{~mm}, \mathrm{~V}_{\mathrm{i}}$-inception voltage of the streamers, $\mathrm{V}_{\mathrm{aE}}$-acceleration voltage of streamers in synthetic ester liquid, $\mathrm{V}_{\mathrm{aM}}$ - acceleration voltage of streamers in mineral oil, red dots-average propagation velocity of streamers in synthetic ester obtained from experiment, red dotted line-regression line for propagation velocity of streamers in synthetic ester, blue dots-average propagation velocity of streamers in mineral oil obtained from experiment, blue dotted line-regression line for propagation velocity of streamers in mineral oil [61]. 
For longer gaps ( $>30 \mathrm{~mm}$ ), the differences between synthetic esters and mineral oils are greater. First, LI-BDV of synthetic esters, as reported in [60], is much lower than that of mineral oil. Additionally, a breakdown in synthetic ester is a result of fast developing streamers, while in mineral oil still slow streamers cause the breakdown independent of the gap distance. This means that the mentioned acceleration voltage is higher in mineral oil, which is its advantage-fast discharges in liquids are attributed to more intense ionization processes, so from the above, in mineral oil these processes appear at the over-voltages of higher values than in the case of synthetic esters. The worst properties of synthetic esters under LI stress are confirmed also by the fact that the differences in propagation velocities of streamers developing in esters and mineral oils increases with an increase in the gap distance.

Streamer characteristics may be also obtained from the analysis of streamer current, electrical charge as well as light emitted by the developing streamers. Streamer currents and emitted light are strongly associated with the streamer mode. The researches on light emission or streamer current in synthetic esters were presented in [60-63,74,78-86]. The main findings from these studies are that the intensity of light as well as the recorded current are always higher in the case of streamers developing in synthetic ester liquids. The light pulses in most cases are of higher peak values and simultaneously of higher frequencies, indicating that more intense ionization processes occur in esters and the branch number of streamers is more important, as shown in Figure 7.

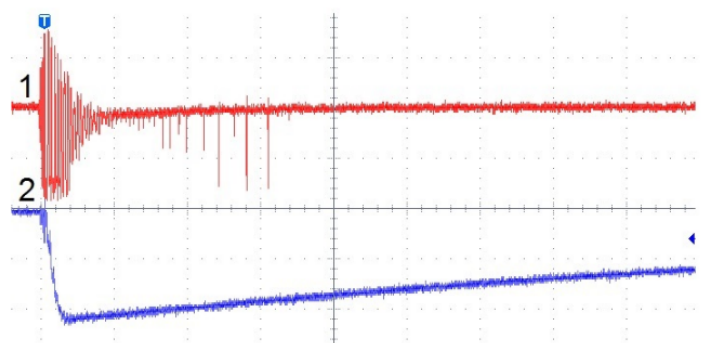

a)

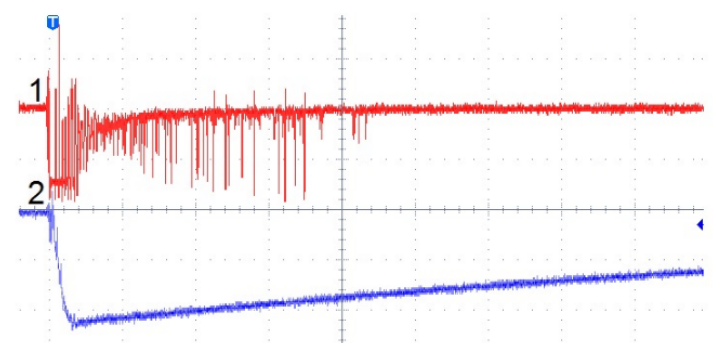

b)

Figure 7. Light and voltage waveforms recorded at LI of negative polarity, $t=4 \mu \mathrm{s} /$ div., $V=50 \mathrm{kV} / \mathrm{div}$., 1-light, 2-voltage, V = $115 \mathrm{kV}$ : (a) mineral oil, (b) synthetic ester.

In conclusion, the lightning performance of synthetic esters are in general of a similar nature when considering the small gaps. This would mean that the phenomena of initiation, development and breakdown of synthetic esters and mineral oils are qualitatively similar. However, when the gaps become longer, the differences are evident, indicating lower resistance of synthetic esters against lightning over-voltages. In general, the transition from slow to fast streamers occurs faster in synthetic esters than in mineral oil. So in terms of lightning performance of synthetic esters, it is a challenge for researchers to analyze the longer gaps, while this is especially important from the viewpoint of the usage of synthetic esters in power transformers of higher nominal voltages. Improving the lightning properties of synthetic esters so that they can be successfully used in high voltage applications is a task that researchers need to address in the near future.

\section{Synthetic Ester-Based Nanofluids}

As was mentioned above, despite the interesting properties of synthetic esters with regard to environmental protection, they present some disadvantages, the main ones of which are their viscosity and impulse breakdown voltage. The viscosity of esters is two to three times higher than that of mineral oils, which constitutes a concern for heat transfer from the transformer windings to the outside, even if the viscosity has a positive effect on the impregnation of insulant papers and pressboards. Thus, with an increase of electric energy demand and, consequently, the increase in energy density, which, in turn, causes an increase of the temperature of the transformer windings, the problem of transformer cooling has become even more crucial. Among others, it is this cooling problem which is at the origin of the introduction of nanoparticles (NPs) into insulating liquids and which has given rise 
to a new class of liquid insulators called nanofluids (NFs). Indeed, it has been well known for many decades that NFs are very efficient for cooling. They are used in many fields such as transportation (exemplary for cooling the systems of heavy power machines), heating buildings and in the reduction of pollution, the cooling of nuclear systems, space and defense (space stations and aircrafts) and electronics (chips, electronic circuitry components) as well as in solar absorption for heat-transfer performance. Their thermal characteristics are better than those of the base fluids. These strongly depend on the properties of added nanoparticles and especially their size, shape, volume fraction and type of material [93-98]. Rafiq et al. in [99] reported that some nanoparticles based on copper, silica and alumina improve thermal conductivity in a linear relationship with the mass fraction in the mixture. These properties, as well as the contact surface between the nanoparticles and the base liquid, are major parameters of influence both on the thermal properties and on the dielectric properties of the nanofluid. Recent work has shown that in addition to improving the heat transfer they provide, nanoparticles also improve the dielectric withstand of insulating liquids [100-109]. These two fundamental properties required for a possible use in high voltage applications, that is, good heat transfer and good dielectric strength make nanofluids possible alternatives for the base oils in oil-based devices. The most frequently used nanoparticles are $\mathrm{TiO}_{2}, \mathrm{Fe}_{3} \mathrm{O}_{4}, \mathrm{SiO}_{2}, \mathrm{Al}_{2} \mathrm{O}_{3}$ and $\mathrm{ZnO}$. Other alternative NPs such as $\mathrm{CuO}, \mathrm{ZrO}_{2}$ and $\mathrm{C} 60$ are also used to increase the dielectric strength of oils [110].

\subsection{Influence of Nanoparticles on the Breakdown Voltage of Synthetic Estes-Based Nanofluids}

The electrical strength of ester-based nanofluids has been investigated at different electrical stresses, such as AC, DC and LI voltages. In general, it is mainly conducting nanoparticles and especially $\mathrm{Fe}_{3} \mathrm{O}_{4} \mathrm{NPs}$ that gives the best improvement of BDV. However, the effect is more pronounced on mineral oil than on esters; the addition of $\mathrm{Fe}_{3} \mathrm{O}_{4}$ NPs to mineral oil can double the AC-BDV of the base mineral oil [111,112]. A similar effect has been also observed with semi-conducting and insulating NPs but with an improvement less important than that with $\mathrm{Fe}_{3} \mathrm{O}_{4}[19,20]$. Unlike mineral oil, the effect of nanoparticles on the dielectric strength of esters and particularly natural esters, is not always so beneficial. Indeed, Peppas et al. $[113,114]$ reported that the addition of $\mathrm{Fe}_{3} \mathrm{O}_{4}$ nanoparticles increases the AC BDV of natural ester oil Envirotemp FR3 up to an optimum value corresponding to a concentration of NPs of $0.008 \%$; the improvement is of about $20 \%$ in relation to the base oil. Beyond this concentration, breakdown voltage drops radically below the BVs of the base oil. These authors also observed that with $\mathrm{SiO}_{2}$ NPS, the AC-BDV is lower than that of the natural ester. Makmud et al. [115] reported that the addition of $\mathrm{Fe}_{3} \mathrm{O}_{4}$ (conductive) and $\mathrm{TiO}_{2}$ (semi-conducting) NPs to a highly refined, bleached, deodorized palm oil (RBDPO) increases the AC-BDV of the base NE.

By considering $\mathrm{Fe}_{3} \mathrm{O}_{4}, \mathrm{Al}_{2} \mathrm{O}_{3}$ and $\mathrm{SiO}_{2}$ nanoparticles, Usama and Beroual [43,112] reported that these NPs do not have a significant influence on the AC-BDV of natural esters (MIDEL 1204) as observed with mineral oil and synthetic esters (MIDEL 7131). Tables 4 and 5 give the mean AC-BDV of natural and synthetic ester-based nanofluids. The best improvement does not exceed $7 \%$. Sometimes, the addition of NPs even decreases the electrical strength of natural esters, as is the case with $\mathrm{SiO}_{2}$ at a concentration of $0.05 \mathrm{~g} / \mathrm{L}$, where the AC-BDV is reduced by $15 \%$ [112]. While it growths slightly by $5 \%$ at $0.2 \mathrm{~g} / \mathrm{L}$ and $4 \%$ at $0.3 \mathrm{~g} / \mathrm{L}$, with $\mathrm{Al}_{2} \mathrm{O}_{3}$ NPS of a size of $50 \mathrm{~nm}$ and at 0.05 and $0.2 \mathrm{~g} / \mathrm{L}$ concentration, the AC-BDVs are lower than the base oil while they are a little bit higher at a concentration of $0.3 \mathrm{~g} / \mathrm{L}$ (by $6 \%$ ); with $0.4 \%$, the improvement is unimportant (1\%). For the same kind of NPs of the size of $13 \mathrm{~nm}$, there is a small improvement at $0.05 \%$ concentration that is at a percentage equal to $7 \%$. 
Table 4. Mean value of AC-BDV of different natural ester (MIDEL 1204)-based nanofluids [112].

\begin{tabular}{|c|c|c|c|c|c|}
\hline & Natural Ester & $\mathrm{Fe}_{3} \mathrm{O}_{4}(50 \mathrm{~nm})$ & $\mathrm{Al}_{2} \mathrm{O}_{3}(50 \mathrm{~nm})$ & $\mathrm{Al}_{2} \mathrm{O}_{3}(13 \mathrm{~nm})$ & $\mathrm{SiO}_{2}(50 \mathrm{~nm})$ \\
\hline \multicolumn{6}{|c|}{ Natural ester/0.05 (g/L) Nanofluids } \\
\hline $\begin{array}{c}\text { Breakdown } \\
\text { voltage }(\mathrm{kV})\end{array}$ & 68.77 & 57.53 & 61.53 & 73.93 & 58.20 \\
\hline \multicolumn{6}{|c|}{ Natural ester/0.2 (g/L) Nanofluids } \\
\hline $\begin{array}{c}\text { Breakdown } \\
\text { voltage }(\mathrm{kV})\end{array}$ & 68.77 & 66.90 & 66.10 & 69.87 & 72.23 \\
\hline \multicolumn{6}{|c|}{ Natural ester/0.3 (g/L) Nanofluids } \\
\hline $\begin{array}{c}\text { Breakdown } \\
\text { voltage }(\mathrm{kV})\end{array}$ & 68.77 & 69.53 & 73.00 & 67.33 & 72.73 \\
\hline \multicolumn{6}{|c|}{ Natural ester/0.4 (g/L) Nanofluids } \\
\hline $\begin{array}{c}\text { Breakdown } \\
\text { voltage }(\mathrm{kV})\end{array}$ & 68.77 & 73.63 & 69.07 & 67.30 & 67.13 \\
\hline
\end{tabular}

Table 5. Mean value of AC-BDV of different synthetic ester (MIDEL 7131)—based nanofluids [43].

\begin{tabular}{|c|c|c|c|c|c|}
\hline & $\begin{array}{l}\text { Synthetic } \\
\text { Ester }\end{array}$ & $\mathrm{Fe}_{3} \mathrm{O}_{4}(50 \mathrm{~nm})$ & $\mathrm{Al}_{2} \mathrm{O}_{3}(50 \mathrm{~nm})$ & $\mathrm{Al}_{2} \mathrm{O}_{3}(13 \mathrm{~nm})$ & $\mathrm{SiO}_{2}(50 \mathrm{~nm})$ \\
\hline \multicolumn{6}{|c|}{ Synthetic ester/0.05 (g/L) Nanofluids } \\
\hline $\begin{array}{c}\text { Breakdown } \\
\text { voltage }(\mathrm{kV})\end{array}$ & 60 & 56.57 & 66.3 & 80.83 & 71.5 \\
\hline \multicolumn{6}{|c|}{ Synthetic ester/0.2 (g/L) Nanofluids } \\
\hline $\begin{array}{c}\text { Breakdown } \\
\text { voltage }(\mathrm{kV})\end{array}$ & 60 & 59.97 & 74.3 & 79.87 & 72.5 \\
\hline \multicolumn{6}{|c|}{ Synthetic ester/0.3 (g/L) Nanofluids } \\
\hline $\begin{array}{c}\text { Breakdown } \\
\text { voltage }(\mathrm{kV})\end{array}$ & 60 & 70.07 & 75.27 & 72.3 & 74.6 \\
\hline \multicolumn{6}{|c|}{ Synthetic ester/0.4 (g/L) Nanofluids } \\
\hline $\begin{array}{c}\text { Breakdown } \\
\text { voltage }(\mathrm{kV})\end{array}$ & 60 & 88.67 & 74.03 & 69.9 & 78.9 \\
\hline
\end{tabular}

The adding of the same NPs to MIDEL 7131 improves its dielectric strength [43]. For a given type of nanoparticles and their sizes, an optimal concentration exists that gives the highest value of AC-BDV. The best improvement is obtained with $\mathrm{Fe}_{3} \mathrm{O}_{4}(50 \mathrm{~nm})$ NPs. It is of $48 \%$ with $\mathrm{Fe}_{3} \mathrm{O}_{4}(50 \mathrm{~nm})$, while it is of 35 and $25 \%$ with $\mathrm{Al}_{2} \mathrm{O}_{3}$ (13 and $50 \mathrm{~nm}$ in size respectively), and it is of $32 \%$ with $\mathrm{SiO}_{2}$ $(50 \mathrm{~nm})$. Thus, synthetic ester-based NFs are found to be more beneficial than natural ester-based NFs.

Mohamad et al. [44] reported that the addition of $0.01 \mathrm{~g} / \mathrm{L}$ of $\mathrm{Fe}_{3} \mathrm{O}_{4} \mathrm{NPs}$ to Palm Fatty Acid Ester (PFAE) improves the AC-BDV compared to pure PFAE by 43\%. Menlik et al. [26] also observed that the adding of silica-coated titanium $\left(\mathrm{ST} \mathrm{TiO}_{2}\right)$ to ENVITRAFOL (a biodegradable oil) at a concentration of $0.25 \%$ increases the AC-BDV by about $33 \%$.

As concerns synthetic esters, it has been reported that $\mathrm{Fe}_{3} \mathrm{O}_{4}, \mathrm{Al}_{2} \mathrm{O}_{3}$ and $\mathrm{SiO}_{2} \mathrm{NPs}$ improve the dielectric strength of MIDEL 7131. The improvement can reach $48 \%$ with $0.4 \mathrm{~g} / \mathrm{L}$ of $\mathrm{Fe}_{3} \mathrm{O}_{4}(50 \mathrm{~nm})$. While it is of 35 and $25 \%$ with $\mathrm{Al}_{2} \mathrm{O}_{3}$ for NPs of sizes 13 and $50 \mathrm{~nm}$, respectively, and $32 \%$ with $\mathrm{SiO}_{2}$ (50 nm).

Regarding the influence of NPs on the DC-BDV of esters, Beroual et al. [46,47] investigated three types of NPs, namely $\mathrm{Fe}_{3} \mathrm{O}_{4}, \mathrm{Al}_{2} \mathrm{O}_{3}$ and $\mathrm{SiO}_{2}$. They observed that, for the $0.05 \mathrm{~g} / \mathrm{L}$ concentration, the DC-BDV of natural ester MIDEL 1204 decreases despite the type of NP. The best improvements are for $0.2 \mathrm{~g} / \mathrm{L}$ of $\mathrm{Fe}_{3} \mathrm{O}_{4}(50 \mathrm{~nm})$ and for $0.3 \mathrm{~g} / \mathrm{L}$ of $\mathrm{Al}_{2} \mathrm{O}_{3}(50 \mathrm{~nm})$; these improvements are around 
$10.6 \%$ and 9\%, respectively. The highest improvement of DC-BDV is noticed for $\mathrm{Al}_{2} \mathrm{O}_{3} \mathrm{NPs}(13 \mathrm{~nm})$, which is $7.6 \%$ for $0.4 \mathrm{~g} / \mathrm{L}$. However, the reduction of DC-BDV is observed independently of the concentration of $\mathrm{SiO}_{2}$. The same authors also analyzed the effect of the same NPs on synthetic esters (MIDEL 7131) and observed the existence of an optimal concentration of NPs that gives the highest DC-BDV with the exception of $\mathrm{SiO}_{2}$, which decreases the DC-BDV of pure synthetic esters, irrespective of the concentration. For the other types of NPs, the DC-BDV is enhanced by circa $25 \%, 13 \%$ and $10 \%$, with $\mathrm{Al}_{2} \mathrm{O}_{3}(13 \mathrm{~nm}), \mathrm{Al}_{2} \mathrm{O}_{3}(50 \mathrm{~nm})$ and $\mathrm{Fe}_{3} \mathrm{O}_{4}(50 \mathrm{~nm}) \mathrm{NPs}$ at the optimal concentration that is $0.05 \mathrm{~g} / \mathrm{L}$, respectively.

By adding silica nanoparticles dispersed in a synthetic ester, Mahidar et al. [48] observed an increase in the corona inception voltage and BDV of NP modified synthetic esters compared to pure synthetic esters; an improvement of approximately $20 \%$ in breakdown voltage is noticed with nano esters compared with pure esters.

As concerns the lightning impulse breakdown voltage (LI-BDV), it has been generally investigated under divergent electric fields and mainly in point-plane electrode configurations. The nanoparticles have generally had a beneficial effect on the LI-BDV of esters. So, Li et al. [116] reported that positive and negative LI-BDVs of vegetable oil (natural ester) based $\mathrm{Fe}_{3} \mathrm{O}_{4}$ nanofluids increase by $37 \%$ and $12 \%$, respectively.

It was shown that in a quasi-uniform electrical field, the adding of $\mathrm{Fe}_{3} \mathrm{O}_{4}, \mathrm{Al}_{2} \mathrm{O}_{3}$ and $\mathrm{SiO}_{2} \mathrm{NPs}$ to natural (MIDEL 1204) and synthetic esters (MIDEL 7131) increased the negative LI-BDV. The best improvement of LI-BDV of synthetic esters is noticed with $\mathrm{Fe}_{3} \mathrm{O}_{4}[117,118]$. The improvement is of about $25.6 \%$ with $\mathrm{Fe}_{3} \mathrm{O}_{4}$ at a concentration of $0.05 \mathrm{~g} / \mathrm{L} ; 22 \%$ with $\mathrm{SiO}_{2}$ at a concentration of $0.3 \mathrm{~g} / \mathrm{L}$; and $18.3 \%$ with $\mathrm{Al}_{2} \mathrm{O}_{3}$ at a concentration of $0.3 \mathrm{~g} / \mathrm{L}$. For natural esters, the best improvements of the U50\% value of LI-BDV are approximately $7.5 \%$ with $\mathrm{Fe}_{3} \mathrm{O}_{4}$ at a concentration of $0.2 \mathrm{~g} / \mathrm{L} ; 16.8 \%$ with $\mathrm{Al}_{2} \mathrm{O}_{3}$ at a concentration of $0.05 \mathrm{~g} / \mathrm{L}$; and $13 \%$ of $\mathrm{SiO}_{2}$ at a concentration of $0.2 \mathrm{~g} / \mathrm{L}[117,118]$.

Note that LI-BDV of pure synthetic esters and natural esters is more that about twice that of BDV at AC stress [117]. By measuring the AC as well as the positive and negative LI breakdown voltages of vegetable oil-based $\mathrm{ZnO}$ nanofluids at different particle concentrations, Chen et al. [119] observed improvements of BDV, these voltages are of $30.2 \%, 24.6 \%$ and $5.5 \%$, respectively.

\subsection{Processes Involved in Breakdown Voltage Mechanisms of Synthetic Esters-Based Nanofluids}

Different mechanisms have been advanced to explain the processes by which NPs affect the breakdown voltage. According to some researchers, the improvement or degradation of the AC-BDV of ester-based nanofluids can be explained by the trapping of electrons by NPs or of slowing the propagation of the streamers [120]. However, there is one fact that seems to be unanimous, it is that of the influence of the dimensions of nanoparticles: for the same type of NPS and concentration, the smaller the nanoparticles, the higher the breakdown voltage of nanofluids is. On the one hand, this is due to the large volume fraction of interfaces in the material bulk and on the other hand the ensuing interactions between the nanomaterial surface charged and the liquid molecule.

According to Beroual and Khaled [46,117], the improvement in the BDV of NP-based esters may be due to (1) the electron trap sites which nanoparticles create around the electrodes by reducing the electron number and consequently by increasing the streamer initiation voltage, thus leading to an increase in the breakdown voltage; and (2) by reducing the number of electrons which move towards the opposite electrode, resulting in an accumulation of electrons at the nanoparticle-surrounding liquid interfaces, thus forming the so-called double layer, and thereby slowing down the propagation of the streamers leading to the breakdown. When the double layer is saturated, the excess electrons will no longer be trapped; they will contribute to the propagation/acceleration of the streamers and thus lead to the reduction of the BDV. This can explain the existence of optimal concentration, a threshold value of NPs beyond which the electrons are no longer trapped.

Some authors such as Du et al. [120], Hwang et al. [121], and Miao et al. [122] explain the improvement of BDV of esters-based nanofluids by the influence of NPs on the streamer development. 
NPs, especially the conducting ones, catch the electrons in their movement and accumulate these electrons on the surfaces, creating a local electric field which will counteract to the external electric field. The NPs act as "electron traps", resulting in a slowdown of streamers, thus finally to increase the breakdown voltage. Such a theory has been developed for magnetic NPs in the presence of LI voltage. The interpretation advanced by Peppas et al. [114], and Makmud et al. [115] on the role of NPs goes in the same direction. Nanoparticles act as kind of electronic scavengers that reduce the charge density and hinder the streamer propagation in nanofluids, resulting in an increase of BDV.

The conductivity of NPs has also an influence on the BDV of NFs. The conductive NPs capture very rapidly fast moving electrons and convert them into slow negatively charged NPs resulting in the slowing streamer development and increasing the breakdown voltage [123]. This can explain why $\mathrm{Fe}_{3} \mathrm{O}_{4}$, conductive NPs, give better results than insulating ones.

According to Ibrahim et al. [124], the dielectric constant of NPs also has an effect on the BDV of NFs. They observed that the adding of iron nickel oxide $\left(\mathrm{Fe}_{2} \mathrm{NiO}_{4}\right) \mathrm{NPs}$ increases the DC-BDV of NFs. NPs of a higher dielectric constant tend to be positively charged while NPs particles of lower dielectric constants have a tendency to be polarized and negatively charged. Both positively and negatively charged NPs can trap streamer electrons. Therefore, both positive and negative DC-BDVs of NF are increased. As for Madawan et al. [125], the improvement of BDV by the addition of magnetic NPs is due to the relaxation time constant of NPs. The time constant value of $\mathrm{Fe}_{3} \mathrm{O}_{4} \mathrm{NPs}$ is low in comparison to that of $\mathrm{Al}_{2} \mathrm{O}_{3} \mathrm{NPs}$. Hence $\mathrm{Fe}_{3} \mathrm{O}_{4}$-based NFs have greater BDV than NFs with other NPs. The NFs with $\mathrm{Fe}_{3} \mathrm{O}_{4} \mathrm{NPs}$ have a higher rate of scavenging of charges from the streamer.

According to Hwang et al. [121], if the polarization-relaxation time of NPs is shorter than the streamer development time, the streamer is inhibited and the BDV increases. In turn, when the time constant is greater than the streamer development time, the streamer and the breakdown voltage are not affected. However, such an interpretation is in contradiction with the results concerning the influence of different types of electronic scavenger compounds (carbon tetrachloride, Iodobenzene or sulfur hexafluoride) $[126,127]$. Indeed, it is well-known that such additives accelerate the propagation of the streamers in liquids [128].

As concerns the influence of the voltage wave form (AC and DC), it can be explained by the injected space charge. Under DC voltage, the injected homo-charges make the liquid more conductive, leading thence to a drop in the breakdown voltage. While under AC voltage, the hetero-charges neutralize each other and their effect on liquid conduction and breakdown voltage is therefore less significant. The mechanisms making DC-BDV higher than AC-BDV in NFs would therefore be different. Thus the conductivity of the liquid at itself cannot explain this difference.

The increase in DC-BDV could be due to the fact that by accumulating on the surface of the nanoparticles, the number of homo-charges injected decreases. The electric field in the vicinity of the injector (that is to say of the HT electrode) and in the volume of the liquid decreases. This results in an increase in the initiation threshold voltage of the streamer and consequently an increase in the DC breakdown voltage.

\section{Combined Paper-Synthetic Ester-Based Insulating Systems}

\subsection{Moisture Equilibrium Curves}

The moisture equilibrium curves describe the dependence of water content in cellulose materials (expressed in percentage by weight) as a function of water content in electro-insulating liquid (expressed in ppm by weight) [30]. Figure 8 shows the equilibrium curves for cellulose insulation impregnated with a synthetic ester. In order to construct these curves, the method proposed by Oommen was used [129]. It consists of combining the curves of water content in electro-insulating liquid (Figure 9) and cellulose paper (Figure 10) as a function of air relative humidity. The curves from Figure 10 were obtained on the basis of water saturation coefficients for synthetic esters. Midel 7131 determined by Round Robin Test carried out by the Cigre D1.52 WG, while the water sorption isotherms 
for new cellulose paper (degree of polymerization equal to 1360) were determined on the basis of data from [32].

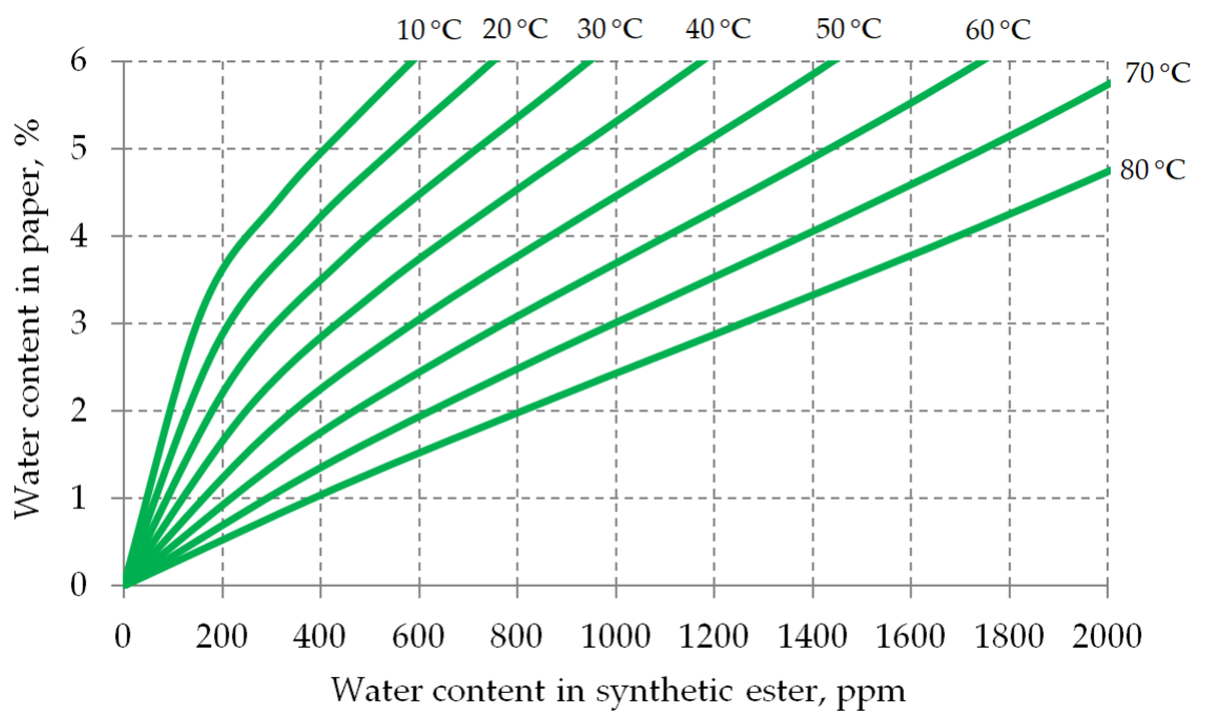

Figure 8. Moisture equilibrium curves for cellulose paper and synthetic ester Midel 7131.

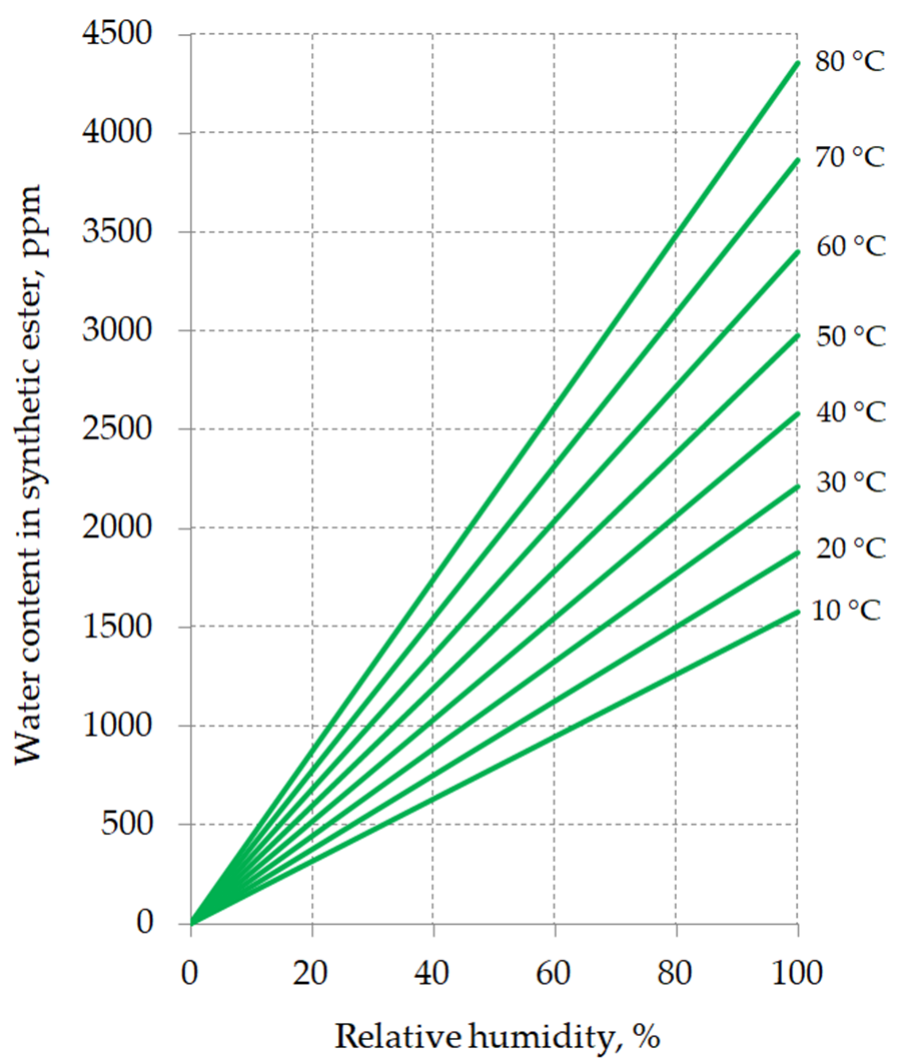

Figure 9. Water content in synthetic ester Midel 7131 of relative humidity, based on the data from [30]. 


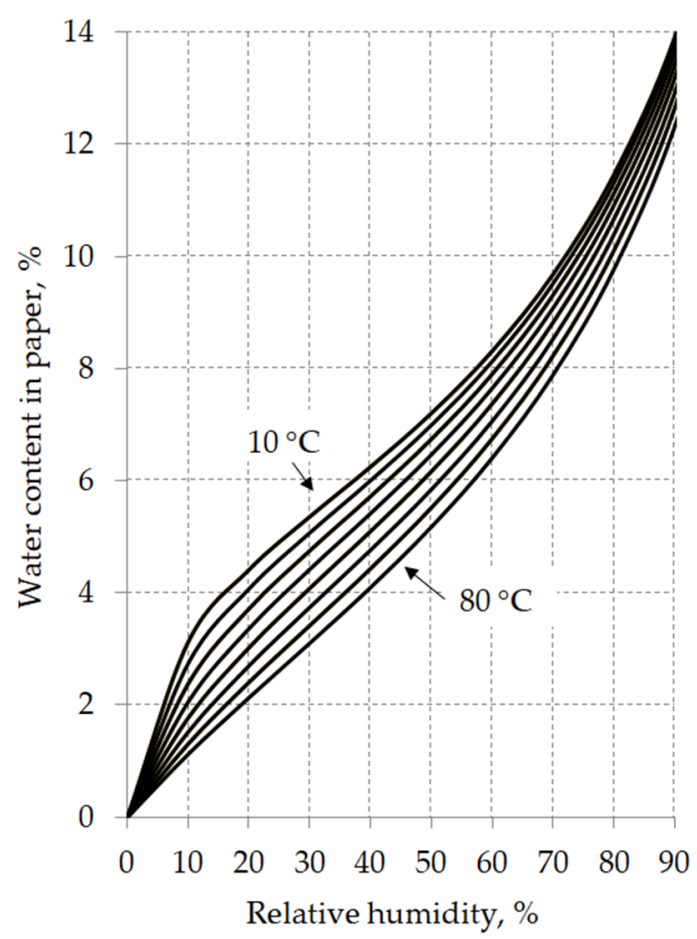

Figure 10. Water sorption isotherms of cellulose paper, based on the data from [32].

The moisture equilibrium curves from Figure 10 show the relationship between the amount of water accumulated in cellulose insulation and the amount of water dissolved in the synthetic ester. They allow, for example, to estimate how the water content in the insulating liquid will change, and thus the degree of ester saturation with water, as a result of changes in the insulation temperature. The moisture equilibrium curves also makes it possible to determine the water content in solid insulation impregnated with a synthetic ester on the basis of information on the water content in this liquid and the insulation temperature. However, it should be remembered that this method of assessing the moisture content of solid insulation has a number of limitations. To use this method, the cellulose-ester system must be in the moisture equilibrium or close to this state, which needs to maintain the temperature at a constant level for a long time. The higher temperature, the shorter time needed to achieve moisture equilibrium. A single measurement of water content in ester by means of the Karl Fischer titration method does not enable the assessment of the dynamics of water migration in the insulation system. An alternative for measuring the water content by the Karl Fischer method is a capacitive sensor, which, when installed on a transformer, gives a broader image of the insulation moisture. Moreover, in order to correctly apply moisture equilibrium curves, it is necessary to take into consideration the influence of the aging rate of both cellulose and liquid insulation $[32,130,131]$.

Table 6 gives the guidelines for interpreting the condition of cellulose insulation on the basis of oil relative saturation. This interpretation was taken from the standard [132] prepared for mineral insulating oils. On the basis of the relative saturation values (Table 6) and the above-quoted water saturation coefficients (Table 2), it is possible to calculate the limit values of water content in synthetic esters for a given temperature, which corresponds to the different conditions of cellulose insulation. The limit values of water content calculated for temperature equal to $50^{\circ} \mathrm{C}$ are shown in Table 6 . 
Table 6. The guidelines for interpreting the condition of cellulose insulation on the basis of water content in synthetic ester.

\begin{tabular}{ccc}
\hline Relative Saturation, \% & $\begin{array}{c}\text { Limit Values of Water Content, ppm } \\
\text { @ } \mathbf{5 0} \mathbf{~}^{\circ} \mathbf{C}\end{array}$ & Condition of Cellulosic Insulation [132] \\
\hline$<5$ & $<149$ & Dry insulation \\
\hline 5 to 20 & 149 to 595 & $\begin{array}{c}\text { Moderately wet, low values indicate fairly dry } \\
\text { to moderate levels of moisture content in the } \\
\text { insulation. The values toward the upper limit } \\
\text { show moderately wet cellulose insulation }\end{array}$ \\
\hline 20 to 30 & 595 to 893 & Wet insulation \\
\hline$>30$ & $>893$ & Extremely wet insulation \\
\hline
\end{tabular}

\subsection{Impregnation of Solid Insulation with Synthetic Esters}

In order to obtain the optimal properties of a liquid-solid insulation structure, the impregnation process of the solid insulation by a given dielectric liquid should be thoroughly carried out. For this reason, it is particularly important to select proper parameters of drying and then impregnation processes, which will ensure a long lifetime of solid insulation and thus the transformer itself. In the case of mineral oil used as the dielectric liquid in power transformer, the manufacturers have possessed a great knowledge in selection of optimal parameters for impregnation process. This knowledge has resulted from the long presence of mineral oil in the transformer market. It is the opposite situation in the case of synthetic esters, which have only recently been used in the transformer applications; the practical knowledge of their behavior in different areas of exploitation is not yet sufficiently mastered.

The impregnation properties of synthetic esters were studied widely by Dai and Wang in [133], and also in a narrow range by Rozga [19] using the capillary effect. Although the capillary test is not a complicated, the results obtained with its use give the data on impregnation efficiency of a given liquid considered. In general, capillary tests concern the phenomenon of pulling up the liquid at the impact of capillary forces it and depends on the specific properties of a given material. The kinematic viscosity of the liquid, the number of open pores contained in the insulating material (pressboard), the diameters of the pores, as well as the pressure outside and inside of the material determine the rate of liquid penetration into the insulating material. In the tests described in [133], the $3 \mathrm{~mm}$ thick pressboard and two types of laminated blocks were investigated. The tests were carried out at selected temperatures of impregnation processes: 20,40 and $60^{\circ} \mathrm{C}$. In the case of the pressboard, the authors indicated that the balance point at which the process of impregnation occurs in a similar way is $60^{\circ} \mathrm{C}$ for synthetic esters and $20^{\circ} \mathrm{C}$ for mineral oil. This finding was confirmed in the tests of laminated blocks where the synthetic ester at $60^{\circ} \mathrm{C}$ impregnated the block identically to the mineral oil at 20 ${ }^{\circ} \mathrm{C}$. Similar findings noticed in [19], where the considered temperatures were $20,60,80$ and $100{ }^{\circ} \mathrm{C}$ and $2 \mathrm{~mm}$ thick pressboard samples were tested. Obtaining similar results of impregnation when using synthetic esters instead of mineral oil, was achieved neither by extending the impregnation time nor by increasing the temperature of the impregnation process. For example, saturation of the pressboard sample at the temperature $100{ }^{\circ} \mathrm{C}$ to the same height as in the case of mineral oil required approximately 1.5 longer time in the case of synthetic esters.

\subsection{Breakdown Characteristics of Solid Insulation Components Impregnated with Synthetic Esters}

The comparison of breakdown characteristics of pressboard samples impregnated with different liquid dielectrics under different drying and impregnation process conditions was done in [41]. In these studies, next to the full impregnation process applied to the $2 \mathrm{~mm}$ thick pressboard samples according to the IEC 60243-1 Standard [134], intermediate conditions were also considered. Thus, in the first cycle called "full impregnation" the samples, after drying under vacuum through $24 \mathrm{~h}$ in $100{ }^{\circ} \mathrm{C}$, were flooded with a given dielectric liquid (mineral oil, natural ester, synthetic ester, respectively) 
and then impregnated in $100{ }^{\circ} \mathrm{C}$ through $24 \mathrm{~h}$. In the second cycle, called " $8 \mathrm{~h}, 60^{\circ} \mathrm{C}$ ", the samples, after drying identically to the first part, were impregnated at $60^{\circ} \mathrm{C}$ for $8 \mathrm{~h}$. In the cycle part called " $8 \mathrm{~h}$, $100{ }^{\circ} \mathrm{C}^{\prime \prime}$, the samples after drying were impregnated at a temperature of $100{ }^{\circ} \mathrm{C}$ for $8 \mathrm{~h}$. The results obtained in the form of a median of 26 breakdowns are presented in Table 7.

Table 7. Median of breakdown voltages of pressboard impregnated in a different ways $(\mathrm{kV})$.

\begin{tabular}{cccc}
\hline Impregnation Cycle & Mineral Oil & Natural Ester & Synthetic Ester \\
\hline $8 \mathrm{~h}, 60^{\circ} \mathrm{C}$ & 38.85 & 38.10 & 37.55 \\
\hline $8 \mathrm{~h}, 100^{\circ} \mathrm{C}$ & 45.50 & 41.80 & 44.00 \\
\hline Full, $24 \mathrm{~h}, 100^{\circ} \mathrm{C}$ & 81.95 & 83.40 & 88.60 \\
\hline
\end{tabular}

The obtained results show some kind of benefit of ester liquids although capillary tests do not demonstrate it. In the case of all impregnation cycles applied, both esters impregnated the pressboard similarly as mineral oil assessing the process from the point of view of electrical strength of pressboard. Especially, full impregnation gave promising results for the synthetic ester because breakdown voltage was a few $\mathrm{kV}$ higher than in the case of the other liquids used for impregnation. As we assume that the first cycle ensures full impregnation of the pressboard samples, the highest electrical strength of the pressboards impregnated with synthetic ester is not a surprise: the synthetic ester has a much higher electrical permittivity (3.2) than mineral oil (2.2). This causes the pressboard to be impregnated with this liquid and also has a greater electrical permittivity, which leads to a decrease in the value of the electric field in the material, i.e., an increase in its electrical strength.

A similar conclusion was formed in [135]. A full impregnation procedure for 0.5 and $1 \mathrm{~mm}$ thick pressboard samples impregnated with esters and mineral oil gives a reflection of the statistically identical electrical strength of pressboards for a whole range of breakdown probabilities assessed using three-parameter Weibull distribution function.

However, breakdown tests of solid insulation showed some disadvantages of esters when observing the marks on the pressboard surfaces left by discharges leading to breakdown. These marks occurred denser in the case of pressboard impregnated with esters. It means that ester-impregnated pressboards are more susceptible to partial discharge influences which are not desirable in real insulating structures. Figure 11 depicts an example of pressboard surfaces after discharge leading to breakdown.

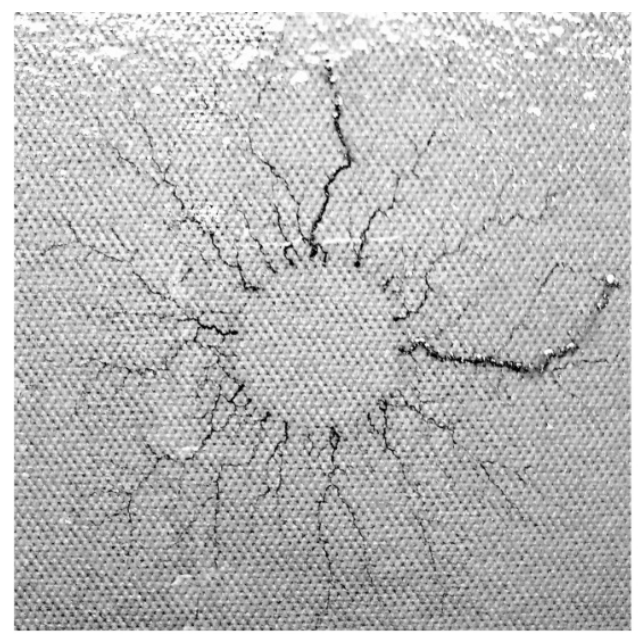

a)

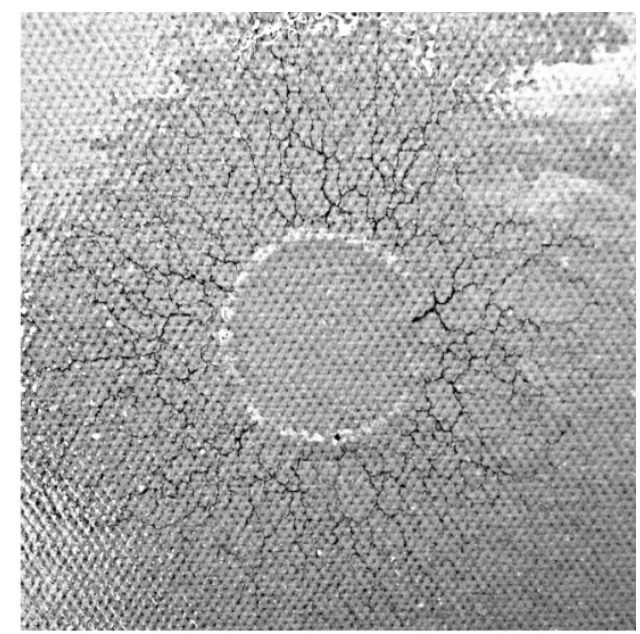

b)

Figure 11. Differences in the shapes of marks due to discharges over the surface of pressboard samples: (a) mineral oil, (b) synthetic ester. 


\subsection{Electric Field Distribution in Insulating Systems with Synthetic Esters}

Insulation structures based on cellulosic materials and synthetic esters have not been the subject of a wide range of studies. Rather, the natural esters are considered in such studies as representative of alternative dielectric liquids [136]. Thus, in [41], the studies in this field were achieved comparing synthetic esters and mineral oil in terms of electrical field distribution in simplified power transformer winding structures. Figure 12 depicts the electric field distribution of the assumed main insulation part isolated with synthetic esters and mineral oil, respectively. It is not easy from this figure to identify the differences. Thus, Figure 13 shows a selected magnified fragment from Figure 12.

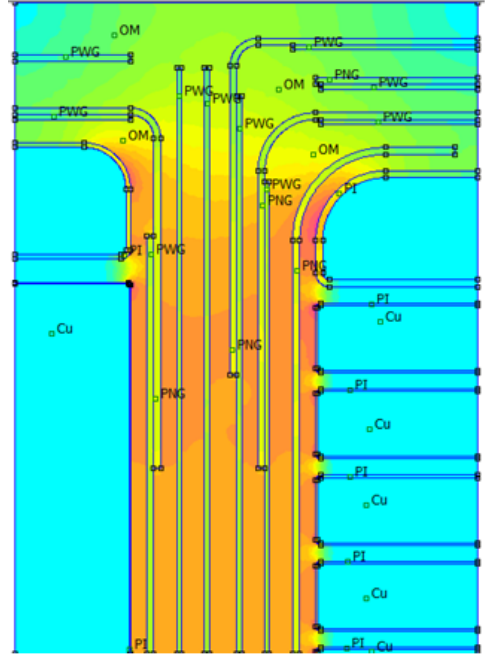

a)

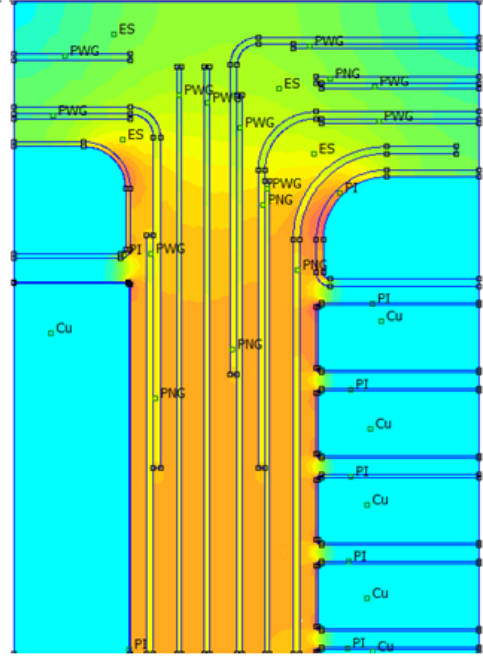

b)

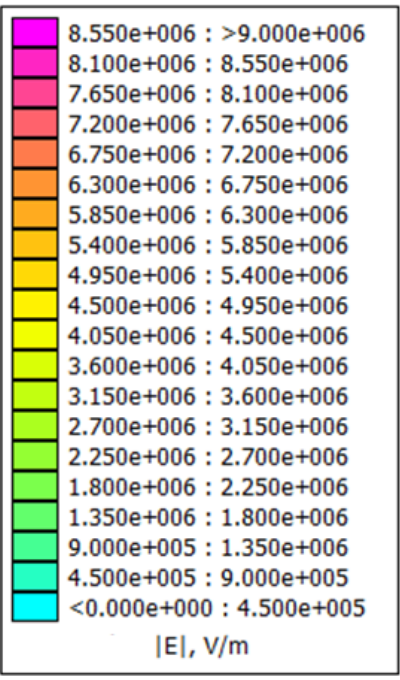

$|E|, V / m$

Figure 12. Electric field distribution in simplified insulation structure of power transformer: (a) mineral oil, (b) synthetic ester.

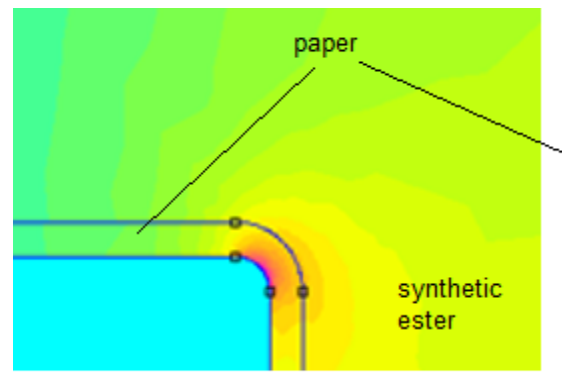

a)

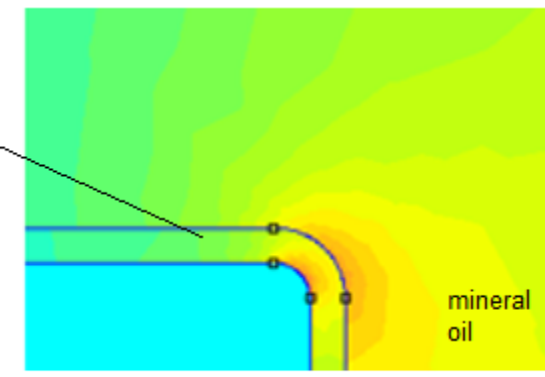

b)

Figure 13. Magnified fragment of electric field distribution in transformer insulation: (a) synthetic ester, (b) mineral oil.

As can be seen, the intensity of electrical field is higher in paper when the synthetic ester is used as a dielectric liquid (concentrated region marked by deep red). However, in the "liquid part", the electric field stress decreases in the case of the synthetic ester where a light orange color is observed, while dark orange appears in the case of mineral oil. The obtained data are not, however, a surprise-higher electrical permittivity of synthetic esters in relation to the mineral oil causes a decrease in the electrical field in this medium at the expense of an increase in the electrical field stress in solid insulation. However, the differences between the distinctive regions are lower in the case of ester liquids, which is their benefit $[41,136]$. 


\section{Application of Synthetic Esters for Retro-Filling and Drying of Mineral Oil-Immersed Transformers}

\subsection{Miscibility}

In accordance with [4], synthetic esters are miscible with mineral oil and natural esters in all proportions. In turn, the synthetic ester is not miscible with silicone oil. There are some reports in the literature that even small concentrations of silicone oil in esters can cause foaming during the process of filling a transformer under a vacuum. The unlimited miscibility of synthetic esters with mineral oil enables the application of esters for retro-filling and drying mineral-oil-immersed transformers. In both situations, the mixture of synthetic esters with oil is formed whose properties differ from both base insulating liquids. This must be considered during the operation and diagnostics of transformers subjected to the retro-filling or drying process.

\subsection{Retro-Filling}

The retro-filling process should be understood as the replacement of insulating liquid in the transformer tank with another type of liquid. In the past, the retro-filling processes were performed mainly for environmental reasons. For example, this was the case with polychlorinated biphenyls (PCBs), which due to their good fire properties, were readily used in transformers between 1930 and the mid-seventies [49]. In the 1970s, it was recognized that PCBs pose a threat to the environment and therefore, the process of their removal began. Ultimately, the owners of PCB transformers had to make the decision either to "replace" the transformers with new non-PCB units or to "reclassify" them to non-PCB status using a retro-filling process [49]. Due to lower costs compared to the purchase of a new unit, the retro-filling process was eagerly chosen by transformer owners. Currently, the retro-filling process is most often associated with the replacement of mineral oil with synthetic or natural esters. The replacement of mineral oil with synthetic esters is performed mainly for two reasons. The first one is related to the better fire properties of esters compared to mineral oil. The second reason is related to synthetic esters being an environmentally friendly liquid which follows from the fact that it is readily biodegradable, unlike mineral oil which is both toxic and non-biodegradable $[4,5,137]$.

The manufacturers of synthetic esters also point to other technical and non-technical benefits related to the replacement of mineral oil with synthetic esters, which include [52]:

- increasing the transformer life; which is related to the superior water tolerance properties of synthetic esters, which increase the life of solid insulation'

- lowering the insurance costs by reducing the likelihood of a serious fire;

- and demonstrating the social responsibility of the transformer owner.

All the technical benefits of the retro-filling mentioned above, especially fire safety, depend to a large extent on the quality of the liquid exchange treatment. The removal of as much of the mineral oil as possible from the transformer tank is of great importance for the properties of the synthetic ester with which the unit will be filled. Unfortunately, it is not possible to completely remove mineral oil, especially from the impregnated cellulose. During the transformer operation, this remaining oil may slowly diffuse to a synthetic ester. Thereby, some of the synthetic ester properties will be affected.

It is estimated that after the retro-filling process, up to $10 \%$ of the mineral oil may remain in the cellulose insulation, but also at the bottom and at the walls of the tank or on the transformer core [49-51]. Moreover, the authors of [51] estimated that for the units they analyzed, in the case of suction of mineral oil from the bottom of the tank and its partial removal from the surface of transformer elements, the oil content in the synthetic ester ranges from $1.2 \%$ to $1.7 \%$. On the other hand, when the oil is drained only to the drain valve level, the content ranges from 8.6 to $9.7 \%$. The ranges shown may vary depending on the fluid exchange technique used, but also depending on factors such as, e.g., the ratio of cellulosic materials to insulating liquid. To reduce the residual mineral oil in the tank, the rinsing procedure of core and windings with a heated ester should be used. 
The presence of mineral oil in the synthetic ester strongly influences the fire properties such as flash and fire points. Figure 14 shows the dependency of the flash and fire points depending on the content of mineral oil in synthetic esters [42]. As can be seen, the fire properties of the liquid decreases with the increasing mineral oil content in the synthetic ester. The decrease in both the flash and fire points is greatest in the range of up to $10 \%$ of the mineral oil content in the synthetic ester. Therefore, it is so important to remove during the process of retro-filling as much mineral oil as possible.

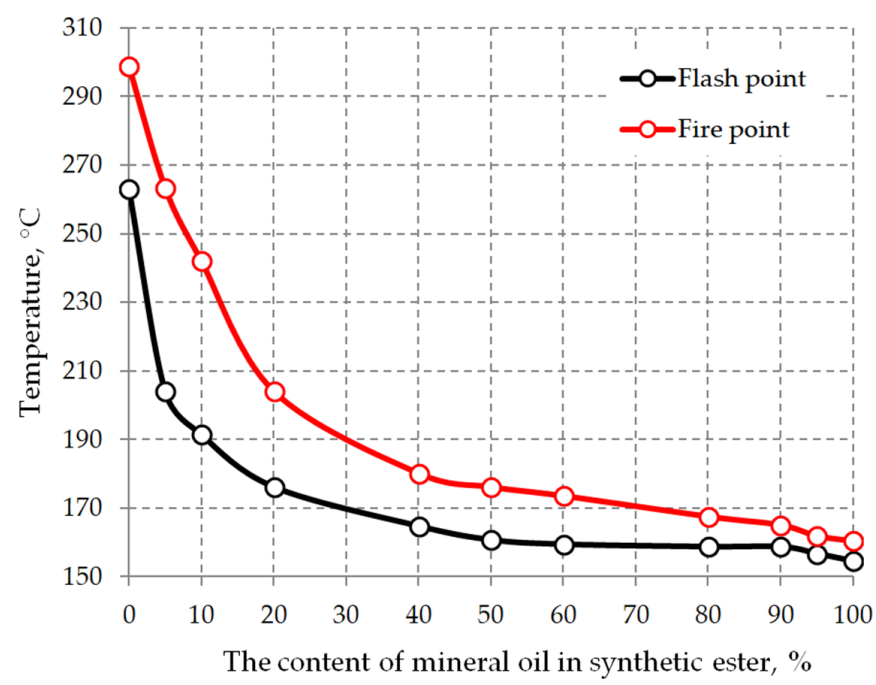

Figure 14. The flash and fire points depending on the content of mineral oil in synthetic ester, on the basis of data from [42].

In accordance with the information from [53], the application of synthetic ester Midel 7131 for retro-filling a transformer depends on the voltage and power rating of the unit. In the case of the distribution transformers up to $33 \mathrm{kV}$, no problems relating to the retro-filling process are anticipated. In turn, for power transformers above $33 \mathrm{kV}$, the additional steps to prepare the transformer for liquid exchange treatment may be necessary. The general guideline for the retro-filling of transformers above $33 \mathrm{kV}$ is given in [53].

\subsection{Drying}

Due to their high water solubility, the ester fluids can be used to dry the transformer cellulose insulation [54,55,138]. The authors of [139] proved that retro-filling a mineral oil-filled power transformer with a natural ester will decrease the cellulose moisture content in cellulose. A better drying effect is to be expected in the case of using a synthetic ester for retro-filling, which can be explained by its greater water solubility $\left(S=3404 \mathrm{ppm}\right.$ at $\left.60^{\circ} \mathrm{C}\right)$ compared to the natural ester $\left(\mathrm{S}=1672 \mathrm{ppm}\right.$ at $\left.60^{\circ} \mathrm{C}\right)$ [32]. In [55], it was proven that the drying of synthetic esters can be effectively carried out for cellulose insulation impregnated with mineral oil. Drying takes place because the ester-cellulose system strives to reach the moisture equilibrium state. After the dry ester is introduced into the tank, the water migrates from the moist cellulose insulation to the ester. The dynamics of water migration, and hence the drying efficiency, is influenced by several factors, including [57]:

- $\quad$ Drying temperature;

- Thickness of cellulose materials;

- Moisture content in the synthetic ester;

- Moisture content in cellulose;

- Weight ratio of ester to cellulose.

The high temperature significantly improves the drying process. The higher temperature insulation, the more water can be dissolved in the ester (Figure 9) and the less water can be adsorbed 
by cellulose (Figure 10). The drying temperature is limited, inter alia, by the temperature class of the materials, which for cellulose is equal to $105^{\circ} \mathrm{C}$, while for thermally upgraded Kraft is $120^{\circ} \mathrm{C}$ [57]. Ensuring a high drying temperature may be difficult, especially in winter conditions. In such a case, a thermal insulation of the transformer tank should be applied [57].

The results of the research presented in [56] show that the amount of water removed from the solid insulation decreases significantly as the thickness of the cellulose material grows. This dependence was observed for cellulose materials up to about $3 \mathrm{~mm}$ thick. Above this value, the effect of the thickness on drying was not observed. This can be explained by the fact that for a short drying time (7 days and $70^{\circ} \mathrm{C}$ ), it is possible to dry only the outer layers of thick cellulose materials.

The influence of the other factors (water content in ester and cellulose or weight ratio of ester to cellulose) on the drying process efficiency depends on the applied drying method. Drying the insulation may result from retro-filling or from the use of synthetic esters for circulating the drying of the transformer insulation system.

In the case of retro-filling, the degree of cellulose insulation drying is limited primarily to the solubility of water in the synthetic ester. After retro-filling, the drying process continues until the migration of water from the cellulose insulation to the ester ceases, that is, until the moisture equilibrium in the cellulose-ester system (Figure 10) is reached. Using the equilibrium curves shown in Figure 10, it is possible to estimate the water content in the transformer after the retro-filling process. The result of such an estimation is presented below, assuming that:

- The moisture content in cellulose materials before retro-filling is equal to $3.0 \%$;

- The average operation temperature of the insulation is equal to $60^{\circ} \mathrm{C}$;

- The initial water content in synthetic ester is equal to $60 \mathrm{ppm}$;

- The weight ratio of the cellulose insulation to the electro-insulating liquid equals 0.0715 for the chosen transformer with a capacity of 10 MVA, a mean of $522 \mathrm{~kg}$ of cellulose and $7300 \mathrm{~kg}$ of mineral oil.

For the conditions so assumed, the use of synthetic ester for the retro-filling process will cause the reduction of water content in cellulose by about 0.75 percentage points, up to the level of $2.25 \%$. It must be pointed out that a single oil replacement with a synthetic ester may give a better or worse drying effect than in the presented calculation example, mainly depending on the weight ratio of cellulose to insulating liquid and the transformer operation temperature.

It is also possible to apply a hot ester circulation method to dry cellulose insulation. This method consists of three stages [57]:

- Replacement of mineral oil with a synthetic ester

- Drying the cellulose insulation by means of the ester, which circulates between the transformer and the equipment for ester drying and heating

- $\quad$ Filling back the transformer tank with mineral oil.

Due to the continuous drying of the synthetic ester, the circulation method allows for a much better drying effect of the transformer solid insulation than in the case of retro-filling. To make drying with circulating ester profitable, it is necessary to develop a method for an industrial system for the treatment of the synthetic ester. This system will allow for reducing the mineral oil concentration in the synthetic ester. The treated ester can be reused many times in the drying process.

\section{DGA-Based Diagnosis of Synthetic Ester-Filled Transformers}

The dissolved gas analysis (DGA) method is one of the most widely used methods for diagnosis on mineral oil-filled transformers, especially power transformers. It makes it possible to detect the beginning of a fault and its location through the detection of certain gases, thereby preventing breakdowns that could lead to significant damage. Indeed, the occurrence of partial discharges (PD) and arcing, overheating and overloading can result in chemical decomposition of the constituents 
of insulating systems, resulting in the formation of different by-products, especially combustible and noncombustible gases dissolved within the insulating liquid. The danger of these gases for the normal operation of the transformer depends on their nature, concentrations, relative proportions and the progression of their concentration. Among the gases used as fault markers, (Hydrogen $\left(\mathrm{H}_{2}\right)$, Carbon monoxide $(\mathrm{CO})$, Carbon dioxide $\left(\mathrm{CO}_{2}\right)$, Methane $\left(\mathrm{CH}_{4}\right)$, Acetylene $\left(\mathrm{C}_{2} \mathrm{H}_{2}\right)$, Ethylene $\left(\mathrm{C}_{2} \mathrm{H}_{4}\right)$ and Ethane $\left.\left(\mathrm{C}_{2} \mathrm{H}_{6}\right)\right)$, Nitrogen $\left(\mathrm{N}_{2}\right)$ and $\left(\right.$ Oxygen $\left(\mathrm{O}_{2}\right)$ are also two gases useful for the diagnosis. Guides and standards using these gases, their concentrations and the relationships existing between them are regularly updated. According to international guidelines for the interpretation of DGA, i.e., IEC 60599 [140] and IEEE C57.104 [141], the three main methods used for mineral oils are: (1) the ratio method; (2) the Duval triangle method; (3) the method of key gases. These are based on the gas kind, the value of the gas and the fault type.

The DGA method has been used for several decades for the diagnosis of transformers filled with mineral oils. Different methods of interpretation are used. However, with the increasing use of liquid insulating substitutes for mineral oils and more particularly for esters (natural or synthetic), the question which arises is that of the extension of the DGA method for the diagnosis of power transformers filled with these alternative oils.

Perrier et al. [70] compared the thermal effect of electrical faults on DGA in esters and mineral oils. For thermal and electrical faults, they focused their studies on the effect of low thermal fault and low energy discharges, respectively. They observed that the same kind of gases (Hydrogen and Acetylene) in comparatively similar ratios are created in esters and mineral oils for electrical faults, and that the classic Duval triangle 1 fits well with this type of fault. For thermal faults as well as for stray gassing issue, Ethane (associated with Hydrogen) is the key gas in the case of natural esters. These authors also showed that new Duval triangles 4 and 6 work well for mineral and ester oils, respectively [69,142,143]. However, with esters, some interpretation care should be taken during vacuum extraction as the results may be underestimated because of the high viscosity of the esters, which could interfere with the results [70].

The DGA of canola-based esters at the discharges of the creepage type reveal that both in the case of esters and mineral oils, similar gases are generated. However, while the quantity of dissolved gases is high in the ester compared to the mineral oil, the key dissolved gas was found to be Hydrogen. $\mathrm{H}$. Mnisi and G. Nyamupangedengu [144] indicated that the Duval triangle and the IEEE-based key gas diagnostic technique with great correctness levels identified the fault while the IEC 60599-based approach failed to identify the fault. According to the authors, the IEC 60599 requires modifications when used in the transformers filled with canola oil.

Gómez et al. [145] investigated two faults, namely discharge and overheating. They considered four different commercial insulating liquids, one mineral oil and three natural esters. They compared five key dissolved hydrocarbon gases-hydrogen $\left(\mathrm{H}_{2}\right)$, methane $\left(\mathrm{CH}_{4}\right)$, ethane $\left(\mathrm{C}_{2} \mathrm{H}_{6}\right)$, ethylene $\left(\mathrm{C}_{2} \mathrm{H}_{4}\right)$ and acetylene $\left(\mathrm{C}_{2} \mathrm{H}_{2}\right)$. They applied in the analysis classic Duval triangle 1, modified Duval triangle 3, Roger's ratio method, the Dornenburg method and the IEC 60599-based method to predict the type of fault. The findings confirmed that modifications are needed to use these method for non-mineral oils when a fault recognition is expected.

Additionally, in [146-148], the authors found that although the gases generated by faults of electrical and thermal origin are the same for mineral oil and esters, it should be pointed out that there is a considerable difference in the amount of the generated gases and the different solubility of these gases in insulating liquids which undoubtedly affects the way the results are interpreted. The example here can be carbon monoxide and dioxide, which are generated in large amounts in the case of thermal exposure to esters [146,147]. Another example is the high portion of Propane in the sum of the gases generated mainly in the synthetic esters during thermal faults type T2 (above $300{ }^{\circ} \mathrm{C}$ ) [148].

According to Lashbrook et al. [149], the methods of dissolved gases analysis applied to mineral oils may be still valid for esters in most cases. However, it is necessary to be vigilant with the stray gassing of ethane in natural esters. This is not seen in mineral oils or in synthetic esters. 


\section{Static Electrification of Synthetic Esters}

The formation of a charge double layer is a natural process for any solid-liquid interphase. When liquid comes into contact with a solid as a result of physicochemical reactions at the interphase, the originally electrically neutral system becomes polarized. The source of the charge are dissociation processes of impurities or additives in the oil. The resulting ions of both signs may react electrochemically with the surface of the solid body in contact with the insulating liquid. These corrosive processes are also a source of electric charge carriers. As a result, a charge layer is created on the surface of the solid and a charge of the opposite sign is formed in the liquid layer near the solid surface. These two layers of charge are called electric double layers (EDL). The EDL formation phenomenon was initially described by Helmholtz. In the Helmholtz model, it is assumed that the charge of the counter-ions forms a monolayer in the liquid. This model was then developed by Gouy and Chapman by assuming the distribution of ions in the liquid as continuous, resulting in a diffusion layer of finite thickness. The Stern model based on both of these models takes into account the existence of both the Helmholtz and Gouy-Chapman layers.

In transformers with a forced oil flow cooling, the EDL layer becomes broken, which results in movement and the local accumulation of space charge. These phenomena in turn are the cause of partial discharges, leading to serious failures of power transformers. This problem has already been noticed in the 1970s [150], and led to an interest in the phenomenon of static electrification of mineral oils [151-154]. Growing ecological requirements made the transformer industry turn to biodegradable oils and oils made from renewable materials. The more common use of a new type of insulating liquid in increasingly larger units is associated with the risk of their failure resulting from static electrification.

The research carried out by various authors indicates a general tendency towards stronger static electrification of esters in relation to mineral oils $[67,68,155]$. As is shown by the research presented by Paillat et al. [156], the electrification current tends to increase with the increasing ester oil rate of movement relative to the solid phase as well as the function of flow time and temperature. Kolcunova et al. [155] explained the increase in the value of current with an increase in the speed of phase movement by the changes in the thickness of the laminar sub-layer in relation to the Debye-length. This is a general property also confirmed for mineral oil by researchers $[157,158]$. However, the current values are higher than for mineral oil.

A comparison of the electrification of mineral oil and esters, presented by Beroual et al. [67], confirms the fact of generating the highest values of electrification currents in the case of ester oil. Moreover, these authors showed that the type of paper or pressboard with which both mineral and ester oil comes into contact has a similar effect on the value of the electrification current. The flow of mineral oil at the surface of the pressboard generates the higher values of the electrification current than in the case of the transformer paper surface, regardless of the flow velocity. Ester oil shows a greater ability to electrification to interact with TU (Thermally Upgraded) paper, for higher rates of phase shift.

The dependence of the value of the electrification current on the degree of roughness of the solid at which the double layer is formed has been reported by Jaroszewski et al. [159] Even a slight increase in the roughness of the dielectric surface entails an increase in the generation of the electrification current. Zdanowski et al. [160] reported similar dependencies.

In addition to the abovementioned factors affecting the level of flow electrification of transformer oils, N'Cho et al. [161] indicated another very important factor increasing electrification currents, which is the contamination by oil aging byproducts.

Although researches clearly showed a higher charge generation by ester oils compared to mineral oils, Zelu et al. [162] indicated a lower risk of ester oils in filled transformers from exposure to electrostatic hazards due to the faster decay of space charge. 


\section{Summary}

This article reviews the state of the art of the selected issues that are important for consideration when synthetic esters are applied in high voltage applications. The literature data as well as the critical comments were presented to be a kind of guide for researchers and industry representatives working with synthetic esters on a daily basis. This was done in a comparative form with relation to the data concerning mineral oil for which the knowledge in each field is quite well recognized. The following issues were raised by the authors: AC and DC breakdown voltage of synthetic esters, LI-BDV and pre-breakdown phenomena of synthetic esters, synthetic ester-based nanofluids, combined paper-synthetic ester-based insulating systems, application of synthetic esters for retro-filling and drying of mineral oil-immersed transformers, DGA-based diagnosis of synthetic ester-filled transformers and static electrification of synthetic esters. In general, the analyzed state-of-the-art methods indicated great development opportunities for synthetic esters. However, researchers still face many challenges, so that the synthetic esters can be applied on a larger scale not only in distribution transformers, but also in the power transformers of a high level of nominal voltages.

Author Contributions: All authors contributed equally in the preparation of the article. All authors have read and agreed to the published version of the manuscript.

Funding: This research received no external funding.

Conflicts of Interest: The authors declare no conflict of interest.

\section{References}

1. Oommen, T.; Claiborne, C.; Mullen, J. Biodegradable electrical insulation fluids. In Proceedings of the Electrical Insulation Conference and Electrical Manufacturing and Coil Winding Conference, Rosemont, IL, USA, 25 September 1997; pp. 465-468. [CrossRef]

2. Gockenbach, E.; Borsi, H. Natural and Synthetic Ester Liquids as alternative to mineral oil for power transformers. In Proceedings of the 2008 Annual Report Conference on Electrical Insulation and Dielectric Phenomena, Quebec City, QC, Canada, 26-29 October 2008; pp. 521-524. [CrossRef]

3. Perrier, C.; Beroual, A. Experimental investigations on insulating liquids for power transformers: Mineral, ester, and silicone oils. IEEE Electr. Insul. Mag. 2009, 25, 6-13. [CrossRef]

4. Martin, R.; Athanassatou, H.; Duart, J.C.; Perrier, C.; Sitar, I.; Walker, J.; Claiborne, C.; Boche, T.; Cherry, D.; Darwin, A.; et al. Experiences in Service with New Insulating Liquids; Cigré Technical Brochure 436; International Council on Large Electric Systems (CIGRE): Paris, France, 2010.

5. Fofana, I. 50 years in the development of insulating liquids. IEEE Electr. Insul. Mag. 2013, 29, $13-25$. [CrossRef]

6. Fernández, I.; Ortiz, A.; Delgado, F.; Renedo, C.; Pérez, S. Comparative evaluation of alternative fluids for power transformers. Electr. Power Syst. Res. 2013, 98, 58-69. [CrossRef]

7. Bathina, V.; Sood, Y.R.; Jarial, R.K. Ester Dielectrics: Current Perspectives and Future Challenges. IETE Tech. Rev. 2016, 34, 448-459. [CrossRef]

8. Rao, U.M.; Fofana, I.; Jaya, T.; Rodriguez-Celis, E.M.; Jalbert, J.; Picher, P. Alternative Dielectric Fluids for Transformer Insulation System: Progress, Challenges, and Future Prospects. IEEE Access 2019, 7, 184552-184571. [CrossRef]

9. Oommen, T. Vegetable oils for liquid-filled transformers. IEEE Electr. Insul. Mag. 2002, 18, 6-11. [CrossRef]

10. McShane, C.; Corkran, J.; Rapp, K.; Luksich, J. Natural Ester Dielectric Fluid Development. In Proceedings of the 2005/2006 IEEE/PES Transmission and Distribution Conference and Exhibition, Dallas, TX, USA, 21-24 May 2006; pp. 18-22. [CrossRef]

11. Liao, R.; Hao, J.; Chen, G.; Ma, Z.; Yang, L. A comparative study of physicochemical, dielectric and thermal properties of pressboard insulation impregnated with natural ester and mineral oil. IEEE Trans. Dielectr. Electr. Insul. 2011, 18, 1626-1637. [CrossRef]

12. Rapp, K.J.; Luksich, J.; Sbravati, A. Application of natural ester insulating liquids in power transformers. In Proceedings of the My Transfo 2014, Turin, Italy, 18-19 November 2014; pp. 1-7. 
13. Sitorus, H.B.; Setiabudy, R.; Bismo, S.; Beroual, A. Jatropha curcas methyl ester oil obtaining as vegetable insulating oil. IEEE Trans. Dielectr. Electr. Insul. 2016, 23, 2021-2028. [CrossRef]

14. Haegele, S.; Vahidi, F.; Tenbohlen, S.; Rapp, K.J.; Sbravati, A. Lightning Impulse Withstand of Natural Ester Liquid. Energies 2018, 11, 1964. [CrossRef]

15. Huang, Z.; Chen, X.; Li, J.; Wang, F.; Zhang, R.; Mehmood, M.A.; Liang, S.; Jiang, T. Streamer characteristics of dielectric natural ester-based liquids under long gap distances. AIP Adv. 2018, 8, 105129. [CrossRef]

16. Tokunaga, J.; Nikaido, M.; Koide, H.; Hikosaka, T. Palm fatty acid ester as biodegradable dielectric fluid in transformers: A review. IEEE Electr. Insul. Mag. 2019, 35, 34-46. [CrossRef]

17. Szewczyk, R.; Vercesi, G. Innovative insulation materials for liquid-immersed transformers. Presented at the DuPont Webinar, 13 March 2015.

18. Rozga, P.; Stanek, M. Comparative analysis of lightning breakdown voltage of natural ester liquids of different viscosities supported by light emission measurement. IEEE Trans. Dielectr. Electr. Insul. 2017, 24, 991-999. [CrossRef]

19. Rozga, P. Comparative assessment of impregnation efficiency of insulating pressboard by selected dielectric esters and mineral oil using capillary action test. Przeglad Elektrotech. 2018, 10, 69-72. (In Polish) [CrossRef]

20. Available online: https://www.cargill.com/bioindustrial/dielectric-fluids (accessed on 12 October 2020).

21. Available online: https://www.midel.com/ (accessed on 12 October 2020).

22. Russel, M.; Lashbrook, M.; Satija, N. Synthetic esters for Power transformers AT > 100 kV. ITMA J. 2013.

23. Dohnal, D.; Frotscher, F. The use of natural and synthetic esters in tap changers for power transformers. CEPSI 2014, E9, 1-9.

24. IEC 61099. Insulating Liquids-Specifications for Unused Synthetic Organic Esters for Electrical Purposes; International Electrotechnical Commission (IEC): Geneva, Switzerland, 2010.

25. Stanek, M. The Use of Measuring the Intensity of Light Emitted by Electrical Discharges Developing in Biodegradable Insulating Esters to Assess Their Lightning Strength. Ph.D. Thesis, Lodz University of Technology, Lodz, Poland, 2019.

26. Liu, Q.; Wang, Z.D. Breakdown and withstand strengths of ester transformer liquids in a quasi-uniform field under impulse voltages. IEEE Trans. Dielectr. Electr. Insul. 2013, 20, 571-579. [CrossRef]

27. Pukel, G.J.; Schwarz, R.; Baumann, F.; Muhr, H.M.; Eberhardt, R.; Wieser, B.; Chu, D. Power transformers with environmentally friendly and low flammability ester liquids. Cigre Sess. 2013, 1-6. [CrossRef]

28. Asano, R.; Page, S.A. Reducing Environmental Impact and Improving Safety and Performance of Power Transformers with Natural Ester Dielectric Insulating Fluids. IEEE Trans. Ind. Appl. 2013, 50, 134-141. [CrossRef]

29. IEC 60814. IEC Insulating Liquids-Oil-Impregnated Paper and Pressboard-Determination of Water by Automatic Coulometric Karl Fischer Titration; International Electrotechnical Commission (IEC): Geneva, Switzerland, 1997.

30. Atanasova-Höhlein, I.; Končan-Gradnik, M.; Gradnik, T.; Čuček, B.; Przybylek, P.; Siodla, K.; Liland, K.B.; Leivo, S.; Liu, Q. Moisture Measurement and Assessment in Transformer Insulation-Evaluation of Chemical Methods and Moisture Capacitive Sensors; Cigré Technical Brochure 741; International Council on Large Electric Systems (CIGRE): Paris, France, 2018.

31. Przybyłek, P. Water solubility in synthetic ester and mixture of ester with mineral oil in aspect of cellulose insulation drying. Prz. Elektrotech. 2016, 10, 92-95. [CrossRef]

32. Przybylek, P. Water saturation limit of insulating liquids and hygroscopicity of cellulose in aspect of moisture determination in oil-paper insulation. IEEE Trans. Dielectr. Electr. Insul. 2016, 23, 1886-1893. [CrossRef]

33. Aralkellian, V.G.; Fofana, I. Water in Oil-Filled, High-Voltage Equipment, Part I: States, Solubility, and Equilibrium in Insulating Materials. IEEE Electr. Insul. Mag. 2007, 23, 15-27. [CrossRef]

34. Jovalekic, M.; Kolb, D.; Tenbohlen, S.; Bates, L.; Szewczyk, R. A methodology for determining water saturation limits and moisture equilibrium diagrams of alternative insulation systems. In Proceedings of the 2011 IEEE International Conference on Dielectric Liquids, Trondheim, Norway, 26-30 June 2011. [CrossRef]

35. Water solubility algorithms for dielectric liquids. In DOMINO ${ }^{T M}$ Application Bulletin; Serial number: MKT-AB 11 Rev B; Doble: Marlborough, MA, USA, 1999.

36. Dombek, G.; Nadolny, Z.; Przybylek, P.; Lopatkiewicz, R.; Marcinkowska, A.; Druzynski, L.; Boczar, T.; Tomczewski, A. Effect of Moisture on the Thermal Conductivity of Cellulose and Aramid Paper Impregnated with Various Dielectric Liquids. Energies 2020, 13, 4433. [CrossRef] 
37. IEC 61203. Synthetic Organic Esters for Electrical Purposes-Guide for Maintenance of Transformer Esters in Equipment; International Electrotechnical Commission (IEC): Geneva, Switzerland, 1992.

38. Martins, M.A.G. Vegetable oils, an alternative to mineral oil for power transformers- experimental study of paper aging in vegetable oil versus mineral oil. IEEE Electr. Insul. Mag. 2010, 26, 7-13. [CrossRef]

39. Martins, M.A.G.; Gomes, A.R. Comparative study of the thermal degradation of synthetic and natural esters and mineral oil: Effect of oil type in the thermal degradation of insulating kraft paper. IEEE Electr. Insul. Mag. 2012, 28, 22-28. [CrossRef]

40. IEC 60156. Insulating Liquids-Determination of the Breakdown Voltage at Power Frequency-Test Method; International Electrotechnical Commission (IEC): Geneva, Switzerland, 2018.

41. Scigala, K. Analysis of the Influence of the Used Dielectric Liquid on the Distribution of the Electric Field in the Insulation System-Solid Insulation-Dielectric Liquid. Master's Thesis, Lodz University of Technology, Lodz, Poland, 2018. (In Polish).

42. Dombek, G.; Gielniak, J. Fire safety and electrical properties of mixtures of synthetic ester/mineral oil and synthetic ester/natural ester. IEEE Trans. Dielectr. Electr. Insul. 2018, 25, 1846-1852. [CrossRef]

43. Khaled, U.; Beroual, A. AC dielectric strength of synthetic ester-based $\mathrm{Fe}_{3} \mathrm{O}_{4}, \mathrm{Al}_{2} \mathrm{O}_{3}$ and $\mathrm{SiO}_{2}$ nanofluids-Conformity with normal and weibull distributions. IEEE Trans. Dielectr. Electr. Insul. 2019, 26, 625-633. [CrossRef]

44. Mohamad, M.S.; Zainuddin, H.; Ghani, S.A.; Chairul, I.S. AC breakdown voltage and viscosity of palm fatty acid ester. J. Electr. Eng. Technol. 2017, 12, 2333-2341. [CrossRef]

45. Mentlik, V.; Trnka, P.; Hornak, J.; Totzauer, P. Development of a Biodegradable Electro-Insulating Liquid and Its Subsequent Modification by Nanoparticles. Energies 2018, 11, 508. [CrossRef]

46. Beroual, A.; Khaled, U.; Alghamdi, A.M. DC Breakdown Voltage of Synthetic Ester Liquid-Based Nanofluids. IEEE Access 2020, 8, 125797-125805. [CrossRef]

47. Khaled, U.; Beroual, A. DC breakdown voltage of natural ester oil-based $\mathrm{Fe}_{3} \mathrm{O}_{4}, \mathrm{Al}_{2} \mathrm{O}_{3}$, and $\mathrm{SiO}_{2}$ nanofluids. Alex. Eng. J. 2020. [CrossRef]

48. Mahidhar, G.D.P.; Sarathi, R.; Taylor, N.; Edin, H. Study on performance of silica nanoparticle dispersed synthetic ester oil under AC and DC voltages. IEEE Trans. Dielectr. Electr. Insul. 2018, 25, 1958-1966. [CrossRef]

49. Fafana, I.; Wasserberg, V.; Borsil, H.; Gockenbach, E. Retrofilling conditions of high voltage transformers. IEEE Electr. Insul. Mag. 2001, 17, 17-30. [CrossRef]

50. Fofana, I.; Wasserberg, V.; Borsi, H.; Gockenbach, E. Preliminary investigations for the retrofilling of perchlorethylene based fluid filled transformer. IEEE Trans. Dielectr. Electr. Insul. 2002, 9, 97-103. [CrossRef]

51. Fatyga, P.; Morańda, H. Evaluation of the Mineral Oil and Synthetic Ester Percentage Composition after Replacing Oil with Ester Fluid in Power Transformer. In Proceedings of the International Conference Transformation, Torun, Poland, 9-11 May 2017. (In Polish).

52. Retrofiling-Upgrading Your Transformer. Available online: https://www.midel.com/midel-in-use/retrofilling/ (accessed on 25 August 2020).

53. Insulect-Energy Blog. Available online: https://insulect.com/energy-blog/can-i-use-midel-fluids-to-retrofilltransformers-at-high-voltages (accessed on 25 August 2020).

54. Wasserberg, V.; Borsi, H.; Gockenbach, E. A new method for drying the paper insulation of power transformers during service. In Proceedings of the Conference Record of the 2000 IEEE International Symposium on Electrical Insulation (Cat. No.00CH37075), Anaheim, CA, USA, 5 April 2002; pp. 251-254. [CrossRef]

55. Przybylek, P. Drying transformer cellulose insulation by means of synthetic ester. IEEE Trans. Dielectr. Electr. Insul. 2017, 24, 2643-2648. [CrossRef]

56. Przybylek, P.; Moranda, H.; Moscicka-Grzesiak, H.; Szczesniak, D. Application of Synthetic Ester for Drying Distribution Transformer Insulation-The Influence of Cellulose Thickness on Drying Efficiency. Energies 2019, 12, 3874. [CrossRef]

57. Przybylek, P.; Moranda, H.; Moscicka-Grzesiak, H.; Cybulski, M. Laboratory Model Studies on the Drying Efficiency of Transformer Cellulose Insulation Using Synthetic Ester. Energies 2020, 13, 3467. [CrossRef]

58. Przybylek, P.; Moranda, H.; Moscicka-Grzesiak, H.; Cybulski, M. Analysis of factors affecting the effectiveness of drying cellulose materials with synthetic ester. IEEE Trans. Dielectr. Electr. Insul. 2020, 27, 1538-1545. [CrossRef] 
59. Dang, V.-H.; Beroual, A.; Perrier, C. Comparative study of streamer phenomena in mineral, synthetic and natural ester oils under lightning impulse voltage. In Proceedings of the 2010 International Conference on High Voltage Engineering and Application, New Orleans, LA, USA, 11-14 October 2010; pp. 560-563. [CrossRef]

60. Liu, Q.; Wang, Z.D. Streamer characteristic and breakdown in synthetic and natural ester transformer liquids under standard lightning impulse voltage. IEEE Trans. Dielectr. Electr. Insul. 2011, 18, 285-294. [CrossRef]

61. Rozga, P. Streamer propagation in small gaps of synthetic ester and mineral oil under lightning impulse. IEEE Trans. Dielectr. Electr. Insul. 2015, 22, 2754-2762. [CrossRef]

62. Rozga, P.; Stanek, M.; Rapp, K. Lightning properties of selected insulating synthetic esters and mineral oil in point-to-sphere electrode system. IEEE Trans. Dielectr. Electr. Insul. 2018, 25, 1699-1705. [CrossRef]

63. Dang, V.-H.; Beroual, A.; Perrier, C. Investigations on streamers phenomena in mineral, synthetic and natural ester oils under lightning impulse voltage. IEEE Trans. Dielectr. Electr. Insul. 2012, 19, 1521-1527. [CrossRef]

64. Rozga, P. Studies on behavior of dielectric synthetic ester under the influence of concentrated heat flux. IEEE Trans. Dielectr. Electr. Insul. 2016, 23, 908-914. [CrossRef]

65. Livesey, P.; Lashbrook, M.; Martin, R. Investigation of the factors affecting the dielectric dissipation factor of synthetic and natural esters. In Proceedings of the 2019 IEEE 20th International Conference on Dielectric Liquids (ICDL), Roma, Italy, 23-27 June 2019. [CrossRef]

66. Graczkowski, A.; Gielniak, J. Influence of impregnating liquids on dielectric response of impregnated cellulose insulation. In Proceedings of the 2010 10th IEEE International Conference on Solid Dielectrics, Potsdam, Germany, 4-9 July 2010. [CrossRef]

67. Beroual, A.; Sadaoui, F.; Coulibaly, M.-L.; Perrier, C. Investigation on static electrification phenomenon of ester liquids and mineral oil. In Proceedings of the 2015 IEEE Conference on Electrical Insulation and Dielectric Phenomena (CEIDP), Ann Arbor, MI, USA, 18-21 October 2015; pp. 391-394. [CrossRef]

68. Zdanowski, M. Streaming electrification of mineral insulating oil and synthetic ester MIDEL. IEEE Trans. Dielectr. Electr. Insul. 2014, 21, 1127-1132. [CrossRef]

69. Duval, M.; Hoehlein, I.; Scatiggio, F.; Cyr, M.; Grisaru, M.; Frotscher, R.; Martins, M.; Bates, L.; Boman, P.; Hall, A.C.; et al. DGA in Non-Mineral Oils and Load Tap Changers and Improved DGA Diagnosis Criteria; CIGRE brochure 443; International Council on Large Electric Systems (CIGRE): Paris, France, 2010.

70. Perrier, C.; Marugan, M.; Beroual, A. DGA comparison between ester and mineral oils. IEEE Trans. Dielectr. Electr. Insul. 2012, 19, 1609-1614. [CrossRef]

71. Martin, D.; Wang, Z.D. Statistical analysis of the AC breakdown voltages of ester based transformer oils. IEEE Trans. Dielectr. Electr. Insul. 2008, 15, 1044-1050. [CrossRef]

72. Wang, X.; Wang, Z.; Noakhes, J. Motion of conductive particles and the effect on AC breakdown strengths of esters. In Proceedings of the 2011 IEEE International Conference on Dielectric Liquids, Trondheim, Norway, 26-30 June 2011. [CrossRef]

73. Dang, V.-H.; Beroual, A.; Perrier, C. Comparative study of statistical breakdown in mineral, synthetic and natural ester oils under AC voltage. IEEE Trans. Dielectr. Electr. Insul. 2012, 19, 1508-1513. [CrossRef]

74. Reffas, A.; Moulai, H.; Béroual, A. Comparison of dielectric properties of olive oil, mineral oil, and other natural and synthetic ester liquids under AC and lightning impulse stresses. IEEE Trans. Dielectr. Electr. Insul. 2018, 25, 1822-1830. [CrossRef]

75. Beroual, A.; Khaled, U.; Noah, P.S.M.; Sitorus, H. Comparative Study of Breakdown Voltage of Mineral, Synthetic and Natural Oils and Based Mineral Oil Mixtures under AC and DC Voltages. Energies 2017, 10, 511. [CrossRef]

76. Xiang, J.; Liu, Q.; Wang, Z.D. Streamer characteristic and breakdown in a mineral oil and a synthetic ester liquid under DC voltage. IEEE Trans. Dielectr. Electr. Insul. 2018, 25, 1636-1643. [CrossRef]

77. Reffas, A.; Beroual, A.; Moulai, H. Comparison of breakdown voltage of vegetable olive with mineral oil, natural and synthetic ester liquids under DC voltage. IEEE Trans. Dielectr. Electr. Insul. 2020, 27, 1691-1697. [CrossRef]

78. Hestad, Ø.L.; Ingebrigsten, S.; Lundgaard, L. Streamer initiation in cyclohexane, midel 7131 and nytro 10X. In Proceedings of the IEEE International Conference on Dielectric Liquids, Coimbra, Portugal, 26 June-1 July 2005; pp. 123-126. [CrossRef] 
79. Liu, Q.; Wang, Z.; Perrot, F. Impulse breakdown voltages of ester-based transformer oils determined by using different test methods. In Proceedings of the 2009 IEEE Conference on Electrical Insulation and Dielectric Phenomena, Virginia Beach, VA, USA, 18-21 October 2009; pp. 608-612. [CrossRef]

80. Ngoc, M.N.; Lesaint, O.; Bonifaci, N.; Denat, A.; Hassanzadeh, M. A comparison of breakdown properties of natural and synthetic esters at high voltage. In Proceedings of the 2010 Annual Report Conference on Electrical Insulation and Dielectic Phenomena, West Lafayette, IN, USA, 17-20 October 2010. [CrossRef]

81. Rozga, P.; Stanek, M.; Cieslinski, D. Comparison of properties of electrical discharges developing in natural and synthetic ester at inception voltage. In Proceedings of the 2013 Annual Report Conference on Electrical Insulation and Dielectric Phenomena, Shenzhen, China, 20-23 October 2013; pp. 891-894. [CrossRef]

82. Denat, A.; Lesaint, O.; Mc Cluskey, F. Breakdown of liquids in long gaps: Influence of distance, impulse shape, liquid nature, and interpretation of measurements. IEEE Trans. Dielectr. Electr. Insul. 2015, 22, 2581-2591. [CrossRef]

83. Rozga, P. Using the light emission measurement in assessment of electrical discharge development in different liquid dielectrics under lightning impulse voltage. Electr. Power Syst. Res. 2016, 140, 321-328. [CrossRef]

84. Rozga, P. Streamer Propagation and Breakdown in a Very Small Point-Insulating Plate Gap in Mineral Oil and Ester Liquids at Positive Lightning Impulse Voltage. Energies 2016, 9, 467. [CrossRef]

85. Liu, Q.; Wang, Z.D. Streamer characteristic and breakdown in synthetic and natural ester transformer liquids with pressboard interface under lightning impulse voltage. IEEE Trans. Dielectr. Electr. Insul. 2011, 18, 1908-1917. [CrossRef]

86. Wang, K.; Wang, F.; Shen, Z.; Lou, Z.; Han, Q.; Li, J.; Trnka, P.; Rozga, P. Breakdown and streamer behavior in homogeneous synthetic trimethylolpropane triesters insulation oil. IEEE Trans. Dielectr. Electr. Insul. 2020, 27, 1501-1507. [CrossRef]

87. IEC 60897. Methods for the Determination of the Lightning Impulse Breakdown Voltage of Insulating Liquids; International Electrotechnical Commission (IEC): Geneva, Switzerland, 1987.

88. Tobazéon, R. Prebreakdown phenomena in dielectric liquids. IEEE Trans. Dielectr. Electr. Insul. 1994, 1, 1132-1147. [CrossRef]

89. Lesaint, O.; Massala, G. Positive streamer propagation in large oil gaps: Experimental characterization of propagation modes. IEEE Trans. Dielectr. Electr. Insul. 1998, 5, 360-370. [CrossRef]

90. Yamashita, H.; Amano, H. Prebreakdown phenomena in hydrocarbon liquids. IEEE Trans. Electr. Insul. 1988, 23, 739-750. [CrossRef]

91. Lesaint, O. Prebreakdown phenomena in liquids: Propagation 'modes' and basic physical properties. J. Phys. D Appl. Phys. 2016, 49, 144001. [CrossRef]

92. Rao, U.M.; Fofana, I.; Beroual, A.; Rozga, P.; Pompili, M.; Calcara, L.; Rapp, K.J. A review on pre-breakdown phenomena in ester fluids: Prepared by the international study group of IEEE DEIS liquid dielectrics technical committee. IEEE Trans. Dielectr. Electr. Insul. 2020, 27, 1546-1560. [CrossRef]

93. Choi, S. Enhancing thermal conductivity of fluids with nanoparticles, Developments and Applications of Non-Newtonian flows. ASME J. Fluids Eng. 1995, 231, 99-105.

94. Xuan, Y.; Li, Q. Heat transfer enhancement of nanofluids. Int. J. Heat Fluid Flow 2000, 21, 58-64. [CrossRef]

95. Eastman, J.A.; Choi, S.U.-S.; Li, S.; Yu, W.; Thompson, L.J. Anomalously increased effective thermal conductivities of ethylene glycol-based nanofluids containing copper nanoparticles. Appl. Phys. Lett. 2001, 78, 718-720. [CrossRef]

96. Choi, S.-S.; Zhang, Z.G.; Yu, W.; Lockwood, F.E.; Grulke, E.A. Anomalous thermal conductivity enhancement in nanotube suspensions. Appl. Phys. Lett. 2001, 79, 2252-2254. [CrossRef]

97. Godson, L.; Raja, B.; Lal, D.M.; Wongwises, S. Enhancement of heat transfer using nanofluids-An overview. Renew. Sustain. Energy Rev. 2010, 14, 629-641. [CrossRef]

98. Puspitasari, P.; Permanasari, A.A.; Shaharun, M.S.; Tsamroh, D.I. Heat transfer characteristics of NiO nanofluid in heat exchanger. AIP Conf. Proc. 2020, 2228, 030023. [CrossRef]

99. Rafiq, M.; Lv, Y.; Li, C. A Review on Properties, Opportunities, and Challenges of Transformer Oil-Based Nanofluids. J. Nanomater. 2016, 1-23. [CrossRef]

100. Segal, V.; Hjortsberg, A.; Rabinovich, A.; Nattrass, D.; Raj, K. AC (60 Hz) and impulse breakdown strength of a colloidal fluid based on transformer oil and magnetite nanoparticles. In Proceedings of the Conference Record of the 1998 IEEE International Symposium on Electrical Insulation (Cat. No.98CH36239), Arlington, VA, USA, 7-10 June 1998; pp. 619-622. [CrossRef] 
101. Zhou, Y.X.; Wang, Y.S.; Tian, J.H.; Sha, Y.C.; Jiang, X.X.; Gao, S.Y.; Sun, Q.H.; Nie, Q. Breakdown characteristics in transformer oil modified by nanoparticles. High Volt. Eng. 2010, 36, 1155-1159.

102. Saidur, R.; Leong, K.; Mohammed, H. A review on applications and challenges of nanofluids. Renew. Sustain. Energy Rev. 2011, 15, 1646-1668. [CrossRef]

103. Mergos, J.A.; Athanassopoulou, M.D.; Argyropoulos, T.G.; Dervos, C.T. Dielectric properties of nanopowder dispersions in paraffin oil. IEEE Trans. Dielectr. Electr. Insul. 2012, 19, 1502-1507. [CrossRef]

104. Du, Y.; Lv, Y.; Li, C.; Chen, M.; Zhong, Y.; Zhou, J.; Li, X.; Zhou, Y. Effect of semiconductive nanoparticles on insulating performances of transformer oil. IEEE Trans. Dielectr. Electr. Insul. 2012, 19, 770-776. [CrossRef]

105. Taha-Tijerina, J.; Narayanan, T.N.; Gao, G.; Rohde, M.; Tsentalovich, D.A.; Pasquali, M.; Ajayan, P.M. Electrically Insulating Thermal Nano-Oils Using 2D Fillers. ACS Nano 2012, 6, 1214-1220. [CrossRef] [PubMed]

106. Kharthik, R.; Raja, T.; Madavan, R. Enhancement of critical characteristics of transformer oil using nanomaterials. Arab. J. Sci. Eng. 2013, 38, 2725-2733. [CrossRef]

107. Lv, Y.; Wang, W.; Ma, K.; Zhang, S.; Zhou, Y.; Li, C.; Wang, Q. Nanoparticle Effect on Dielectric Breakdown Strength of Transformer Oil-Based Nanofluids. In Proceedings of the 2013 Annual Report Conference on Electrical Insulation and Dielectric Phenomena, Shenzhen, China, 20-23 October 2013; pp. 680-682. [CrossRef]

108. Lv, Y.Z.; Zhou, Y.; Li, C.R.; Wang, Q.; Qi, B. Recent progress in nanofluids based on transformer oil: Preparation and electrical insulation properties. IEEE Electr. Insul. Mag. 2014, 30, 23-32. [CrossRef]

109. Mdavan, R.; Balaraman, S. Investigation on effects of different types of nanoparticles on critical parameters of nano-liquid insulation systems. J. Mol. Liq. 2017, 230, 437-444. [CrossRef]

110. Huang, Z.; Li, J.; Yao, W.; Wang, F.; Wan, F.; Tan, Y.; Mehmood, M.A. Electrical and thermal properties of insulating oil-based nanofluids: A comprehensive overview. IET Nanodielectr. 2019, 2, 27-40. [CrossRef]

111. Khaled, U.; Beroual, A. AC Dielectric Strength of Mineral Oil-Based $\mathrm{Fe}_{3} \mathrm{O}_{4}$ and $\mathrm{Al}_{2} \mathrm{O}_{3} \mathrm{Nanofluids}_{\text {. Energies }}$ 2018, 11, 3505. [CrossRef]

112. Khaled, U.; Beroual, A. Statistical Investigation of AC Dielectric Strength of Natural Ester Oil-Based $\mathrm{Fe}_{3} \mathrm{O}_{4}$, $\mathrm{Al}_{2} \mathrm{O}_{3}$, and $\mathrm{SiO}_{2}$ Nano-Fluids. IEEE Access 2019, 7, 60594-60601. [CrossRef]

113. Peppas, G.D.; Danikas, M.G.; Bakandritsos, A.; Charalampakos, V.P.; Pyrgioti, E.C.; Gonos, I.F. Statistical investigation of AC breakdown voltage of nanofluids compared with mineral and natural ester oil. IET Sci. Meas. Technol. 2016, 10, 644-652. [CrossRef]

114. Peppas, G.D.; Charalampakos, V.P.; Pyrgioti, E.C.; Bakandritsos, A.; Polykrati, A.D.; Gonos, I.F. A study on the Breakdown Characteristics of Natural Ester Based Nanofluids with Magnetic Iron Oxide and $\mathrm{SiO}_{2}$ Nanoparticles. In Proceedings of the 2018 IEEE International Conference on High Voltage Engineering and Application (ICHVE), Athens, Greece, 10-13 September 2018. [CrossRef]

115. Makmud, M.Z.H.; Illias, H.A.; Ching, Y.C.; Sarjadi, M.S. Influence of Conductive and Semi-Conductive Nanoparticles on the Dielectric Response of Natural Ester-Based Nanofluid Insulation. Energies 2018, 11, 333. [CrossRef]

116. Li, J.; Zhang, Z.; Zou, P.; Grzybowski, S.; Zahn, M. Preparation of a vegetable oil-based nanofluid and investigation of its breakdown and dielectric properties. IEEE Electr. Insul. Mag. 2012, 28, 43-50. [CrossRef]

117. Beroual, A.; Khaled, U. Statistical Investigation of Lightning Impulse Breakdown Voltage of Natural and Synthetic Ester Oils-Based $\mathrm{Fe}_{3} \mathrm{O}_{4}, \mathrm{Al}_{2} \mathrm{O}_{3}$ and $\mathrm{SiO}_{2}$ Nanofluids. IEEE Access 2020, 8, 112615-112623. [CrossRef]

118. Khaled, U.; Beroual, A. Lightning impulse breakdown voltage of synthetic and natural ester liquids-based $\mathrm{Fe}_{3} \mathrm{O}_{4}, \mathrm{Al}_{2} \mathrm{O}_{3}$ and $\mathrm{SiO}_{2}$ nanofluids. Alex. Eng. J. 2020, 59, 3709-3713. [CrossRef]

119. Chen, G.; Li, J.; Yin, H.; Huang, Z.; Wang, Q.; Liu, L.; Sun, J.; He, J. Analysis of Dielectric Properties and Breakdown Characteristics of Vegetable Insulating Oil with Modified by ZnO Nanoparticles. In Proceedings of the 2018 IEEE International Conference on High Voltage Engineering and Application (ICHVE), Athens, Greece, 10-13 September 2018. [CrossRef]

120. Du, Y.; Lv, Y.; Li, C.; Chen, M.; Zhou, J.; Li, X.; Zhou, Y.; Tu, Y. Effect of electron shallow trap on breakdown performance of transformer oil-based nanofluids. J. Appl. Phys. 2011, 110, 104104. [CrossRef]

121. Hwang, J.G.; Zahn, M.; O'Sullivan, F.M.; Pettersson, L.A.A.; Hjortstam, O.; Liu, R. Effects of nanoparticle charging on streamer development in transformer oil-based nanofluids. J. Appl. Phys. 2010, 107, 014310. [CrossRef] 
122. Miao, J.; Dong, M.; Ren, M.; Wu, X.; Shen, L.; Wang, H. Effect of nanoparticle polarization on relative permittivity of transformer oil-based nanofluids. J. Appl. Phys. 2013, 113, 204103. [CrossRef]

123. Sima, W.; Shi, J.; Yang, Q.; Huang, S.; Cao, X. Effects of conductivity and permittivity of nanoparticle on transformer oil insulation performance: Experiment and theory. IEEE Trans. Dielectr. Electr. Insul. 2015, 22, 380-390. [CrossRef]

124. Ibrahim, M.E.; Abd-Elhady, A.M.; Izzularab, M.A. Effect of nanoparticles on transformer oil breakdown strength: Experiment and theory. IET Sci. Meas. Technol. 2016, 10, 839-845. [CrossRef]

125. Madawan, R.; Kumar, S.S.; Iruthyarajan, M.W. A comparative investigation on effects of nanoparticles on characteristics of natural esters-based nanofluids. Colloids Surf. A 2018, 556, 30-36. [CrossRef]

126. Beroual, A. Electronic and gaseous processes in the prebreakdown phenomena of dielectric liquids. J. Appl. Phys. 1993, 73, 4528-4533. [CrossRef]

127. Beroual, A. Pre-breakdown mechanisms in dielectric liquids and predicting models. In Proceedings of the 2016 IEEE Electrical Insulation Conference (EIC), Montreal, QC, Canada, 19-22 June 2016. [CrossRef]

128. Beroual, A.; Zahn, M.; Badent, A.; Kist, K.; Schwabe, A.J.; Yamashita, H.; Yamazawa, K.; Danikas, M.; Chadband, W.D.; Torshin, Y. Propagation and structure of streamers in liquid dielectrics. IEEE Electr. Insul. Mag. 1998, 14, 6-17. [CrossRef]

129. Oommen, T.V. Moisture equilibrium in paper-oil insulation systems. In Proceedings of the 1983 EIC 6 th Electrical/Electronical Insulation Conference, Chicago, IL, USA, 3-6 October 1983; pp. 162-166.

130. Liao, R.; Lin, Y.; Guo, P.; Liu, H.; Xia, H. Thermal aging effects on the moisture equilibrium curves of mineral and mixed oil-paper insulation systems. IEEE Trans. Dielectr. Electr. Insul. 2015, 22, 842-850. [CrossRef]

131. Koch, M.; Tenbohlen, S.; Stirl, T. Diagnostic Application of Moisture Equilibrium for Power Transformers. IEEE Trans. Power Deliv. 2010, 25, 2574-2581. [CrossRef]

132. IEC 60422. Mineral Insulating Oils in Electrical Equipment-Supervision and Maintenance Quidance; International Electrotechnical Commission (IEC): Geneva, Switzerland, 2013.

133. Dai, J.; Wang, Z.D. A Comparison of the Impregnation of Cellulose Insulation by Ester and Mineral oil. IEEE Trans. Dielectr. Electr. Insul. 2008, 15, 374-381. [CrossRef]

134. IEC 60243-1. Electric Strength of Insulating Materials-Test Methods-Part 1: Tests at Power Frequencies; International Electrotechnical Commission (IEC): Geneva, Switzerland, 2013.

135. Rozga, P. Using the three-parameter Weibull distribution in assessment of threshold strength of pressboard impregnated by different liquid dielectrics. IET Sci. Meas. Technol. 2016, 10, 665-670. [CrossRef]

136. Sbravati, A.; Rapp, K.; Schmitt, P.; Krause, C. Transformer insulation structure for dielectric liquids with higher permittivity. In Proceedings of the 2017 IEEE 19th International Conference on Dielectric Liquids (ICDL), Manchester, UK, 25-29 June 2017. [CrossRef]

137. Dombek, G.; Nadolny, Z.; Marcinkowska, A. Effects of Nanoparticles Materials on Heat Transfer in Electro-Insulating Liquids. Appl. Sci. 2018, 8, 2538. [CrossRef]

138. Villarroel, R.; García, B.; García, D.F.; Burgos, J.C. Assessing the Use of Natural Esters for Transformer Field Drying. IEEE Trans. Power Deliv. 2014, 29, 1894-1900. [CrossRef]

139. Moore, S.; Rapp, K.; Baldyga, R. Transformer insulation dry out as a result of retrofilling with natural ester fluid. In Proceedings of the IEEE PES Transmission \& Distribution Conference \& Exposition, Orlando, FL, USA, 7-10 May 2012. [CrossRef]

140. IEC 60599. Mineral Oil-Impregnated Electical Equipment in Service-Guide to the Interpretation of Dissolved and Free Gases Analysis, 2nd ed.; International Electrotechnical Commission (IEC): Geneva, Switzerland, 1999.

141. IEEE C57.104. IEEE Guide for the Interpretation of Gases Generated in Oil-Immersed Transformers; IEEE: New York, NY, USA, 2008.

142. Duval, M. The duval triangle for load tap changers, non-mineral oils and low temperature faults in transformers. IEEE Electr. Insul. Mag. 2008, 24, 22-29. [CrossRef]

143. Duval, M.; Baldyga, R. Stray gassing of FR3 oils in transformers in service. In Proceedings of the 76th International Conference on Doble Clients, Boston, USA, 29 March 2009.

144. Mnisi, H.; Nyamupangedengu, C. Dissolved Gases Analysis of canola-based ester oil under creepage discharge. In Proceedings of the 2020 International SAUPEC/RobMech/PRASA Conference, Cape Town, South Africa, 29-31 January 2020. [CrossRef] 
145. Gómez, N.A.; Wilhelm, H.M.; Santos, C.C.; Stocco, G.B. Dissolved gas analysis (DGA) of natural ester insulating fluids with different chemical compositions. IEEE Trans. Dielectr. Electr. Insul. 2014, 21, 1071-1078. [CrossRef]

146. Hanson, D.; Li, K.; Plascencia, J.; Beauchemin, C.; Claiborne, C.; Cherry, D.; Frimpong, G.; Luksich, J.; Lemm, A.; Martin, R. Understanding dissolved gas analysis of ester liquids: An updated review of gas generated in ester liquid by stray gassing, thermal decomposition and electrical discharge. In Proceedings of the 2016 IEEE Electrical Insulation Conference (EIC), Montreal, QC, Canada, 19-22 June 2016; pp. 138-144. [CrossRef]

147. Przybyłek, P.; Gielniak, J. Concentration analysis of gases formed in mineral oil, natural ester, and synthetic ester by discharges of high energy. Ekspolatacja Niezawodn. Maint. Reliab. 2018, 20, 435-442. [CrossRef]

148. Przybylek, P.; Gielniak, J. Analysis of Gas Generated in Mineral Oil, Synthetic Ester, and Natural Ester as a Consequence of Thermal Faults. IEEE Access 2019, 7, 65040-65051. [CrossRef]

149. Lashbrook, M.; Al-Amin, H.; Martin, R. Natural ester and synthetic ester fluids, applications and maintenance. In Proceedings of the 2017 10th Jordanian International Electrical and Electronics Engineering Conference (JIEEEC), Amman, Jordan, 16 May 2017.

150. Crofts, D. The electrification phenomena in power transformers. IEEE Trans. Electr. Insul. 1988, 23, $137-146$. [CrossRef]

151. Yamada, N.; Kishi, A.; Nitta, T.; Tanaka, T.; Ima, Y. Model Approach to the Static Electrification Phenomena Induced by the Flow of Oil in Large Power Transformers. IEEE Trans. Power Appar. Syst. 1980, 99, 1097-1106. [CrossRef]

152. Shimizu, S.; Murata, H.; Honda, M. Electrostatics in Power Transformers. IEEE Trans. Power Appar. Syst. 1979, 98, 1244-1250. [CrossRef]

153. Radwan, R.; El-Dewieny, R.; Metwally, I.A. Investigation of static electrification phenomenon due to transformer oil flow in electric power apparatus. IEEE Trans. Electr. Insul. 1992, 27, 278-286. [CrossRef]

154. Peyraque, L.; Beroual, A.; Buret, F. Static electrification induced by oil flow in power transformers. Intern. Symp. Electr. Insul. 1996, 2, 745-749. [CrossRef]

155. Kolcunová, I.; Kurimský, J.; Cimbala, R.; Petráš, J.; Dolnik, B.; Džmura, J.; Balogh, J. Contribution to static electrification of mineral oils and natural esters. J. Electrost. 2017, 88, 60-64. [CrossRef]

156. Paillat, T.; Zelu, Y.; Morin, G.; Perrier, C. Ester oils and flow electrification hazards in power transformers. IEEE Trans. Dielectr. Electr. Insul. 2012, 19, 1537-1543. [CrossRef]

157. Vihacencu, M.; Dumitran, L.M.; Nothinger, P.V. Transformer Mineral Oil Electrification. In Proceedings of the 7th International Symposium on Advanced Topics in Electrical Engineering (ATEE), Bucharest, Romania, 12-14 May 2011.

158. Kedzia, J.; Willner, B. Electrification current in the spinning disk system. IEEE Trans. Dielectr. Electr. Insul. 1994, 1, 58-62. [CrossRef]

159. Jaroszewski, M. Electrification currents measurements of natural ester obtained by rotating disc method. Przeglad Elektrotech. 2016, 1,90-93. [CrossRef]

160. Zdanowski, M.; Wolny, S.; Zmarzly, D.; Kedzia, J. The analysis and selection of the spinning disk system parameters for the measurement of static electrification of insulation oils. IEEE Trans. Dielectr. Electr. Insul. 2007, 14, 480-486. [CrossRef]

161. N'Cho, J.S.; Fofana, I.; Beroual, A. Parameters affecting the static electrification of aged transformer oils. In Proceedings of the 2011 Annual Report Conference on Electrical Insulation and Dielectric Phenomena, Cancun, Mexico, 16-19 October 2011; pp. 571-574. [CrossRef]

162. Zelu, Y.; Paillat, T.; Morin, G.; Perrier, C.; Saravolac, M. Study on flow electrification hazards with ester oils. In Proceedings of the 2011 IEEE International Conference on Dielectric Liquids, Trondheim, Norway, 26-30 June 2011. [CrossRef]

Publisher's Note: MDPI stays neutral with regard to jurisdictional claims in published maps and institutional affiliations. 